\title{
Mechanisms of fast flow in Jakobshavn Isbræ, West Greenland: Part III. Measurements of ice deformation, temperature and cross-borehole conductivity in boreholes to the bedrock
}

\author{
Martin LÜTHI ${ }^{1}$ Martin FUnK, ${ }^{1}$ Almut IKEN, ${ }^{1}$ Shivaprasad GOGINENi, ${ }^{2}$ Martin TRUFFER ${ }^{1,3}$ \\ ${ }^{1}$ Versuchsanstalt für Wasserbau, Hydrologie und Glaziologie, Eidgenössische Technische Hochschule, ETH-Zentrum, CH-8092 Zürich, Switzerland \\ E-mail:funk@vaw.baug.ethz.ch \\ ${ }^{2}$ Radar Systems and Remote Sensing Laboratory, University of Kansas 2335, Irving Hill Road, Lawrence, Kansas 66045-7612, U.S.A. \\ ${ }^{3}$ Geophysical Institute, University of Alaska Fairbanks, 903 Koyukuk Drive, P.O. Box 757320, Fairbanks, Alaska 99775-7320, U.S.A.
}

\begin{abstract}
At a site on the ice sheet adjacent to the Jakobshavn ice stream in West Greenland, ice deformation rates and temperatures have been measured in boreholes to the bedrock at $830 \mathrm{~m}$ depth. Enhanced deformation rates were recorded just below the Holocene-Wisconsin transition at $680 \mathrm{~m}$ depth. A $31 \mathrm{~m}$ layer of temperate ice and the temperature minimum of $-22^{\circ} \mathrm{C}$ at $520 \mathrm{~m}$ depth were detected. The good agreement of these data with results of a two-dimensional thermomechanically coupled flow model implies that the model input is adequate. Discrepancies between modelled and measured temperature profiles on a flowline at the ice-stream centre have been attributed to effects not accounted for by the model. We have suggested that the convergent three-dimensional flow leads to a vertical extension of the basal ice entering the stream. A thick basal layer of temperate and Wisconsin ice would explain the fast flow of this ice stream. As a test of this hypothesis, the new core-borehole conductivity (CBC) method has been used to compare conductivity sequences from the ice stream to those of the adjacent ice sheet. The correlation thus inferred suggests that the lowest $270 \mathrm{~m}$ of the ice sheet correspond to the lowermost $1700 \mathrm{~m}$ of the stream, and, consequently, that the lower part of the ice stream has experienced a very large vertical extension.
\end{abstract}

\section{INTRODUGTION}

The western coastal region of the Greenland ice sheet exhibits large areas with temperate bed conditions where fast ice flow occurs. Especially in the Jakobshavn basin, draining $6.5 \%$ of the Greenland ice sheet into Disko Bay, high mass fluxes have been observed (Carbonell and Bauer, 1968; Fastook and others, 1995). Ice flow is occasionally concentrated in regions of narrow lateral extent where very fast ice streams form. The fastest of these is Jakobshavn Isbræ with a velocity of about $7 \mathrm{Km} \mathrm{a}^{-1}$ at the calving front and an estimated calving flux of 25-28 km $\mathrm{km}^{3} \mathrm{a}^{-1}$ (Carbonell and Bauer, 1968; Lingle and others, 1981; Echelmeyer and Harrison, 1990; Echelmeyer and others, 1992). Jakobshavn Isbræ flows through a deeply eroded bedrock trough which extends about $80 \mathrm{~km}$ inland of the calving front, as indicated in Figure 1 (Clarke and Echelmeyer, 1996). Thermomechanically coupled flow models in two and three dimensions have revealed that a basal layer of temperate ice would form in the coastal region as an effect of the geometry, the surface temperature and the mass-balance distribution alone (Budd and others, 1982; Letréguilly and others, 1991; Funk and others, 1994; Greve, 1997). An interesting implication is that ice streams are secondary features of the high mass fluxes and temperate bed conditions.

\section{PREVIOUS BOREHOLE INVESTIGATIONS ON THE ICE STREAM}

Englacial temperatures have been recorded in boreholes on Jakobshavn Isbræ, $50 \mathrm{~km}$ upstream from the calving front (Iken and others, 1993). The holes, drilled with a hot-water system, reached the bed near the ice-stream margins at approximately $1600 \mathrm{~m}$, but stopped far above the bed in the ice-stream centre where the ice thickness is $2500 \mathrm{~m}$. At the centre line, the shape of the measured temperature profile differed substantially from that of a modelling study (Funk and others, 1994). This discrepancy was attributed to convergent three-dimensional flow into the bedrock channel, not accounted for by the two-dimensional model. It was suggested that the convergent flow causes enhanced vertical extension of the basal ice at the centre line and thereby a thickening of the temperate ("soft") basal layer. This could explain the high flow velocity of this ice stream.

\section{GOALS OF THE STUDY}

A better understanding of the specific dynamics of the ice stream is obtained by investigating the conditions in the adjacent ice sheet where the ice is of the same origin, but where flow conditions are less complex. In this study we 

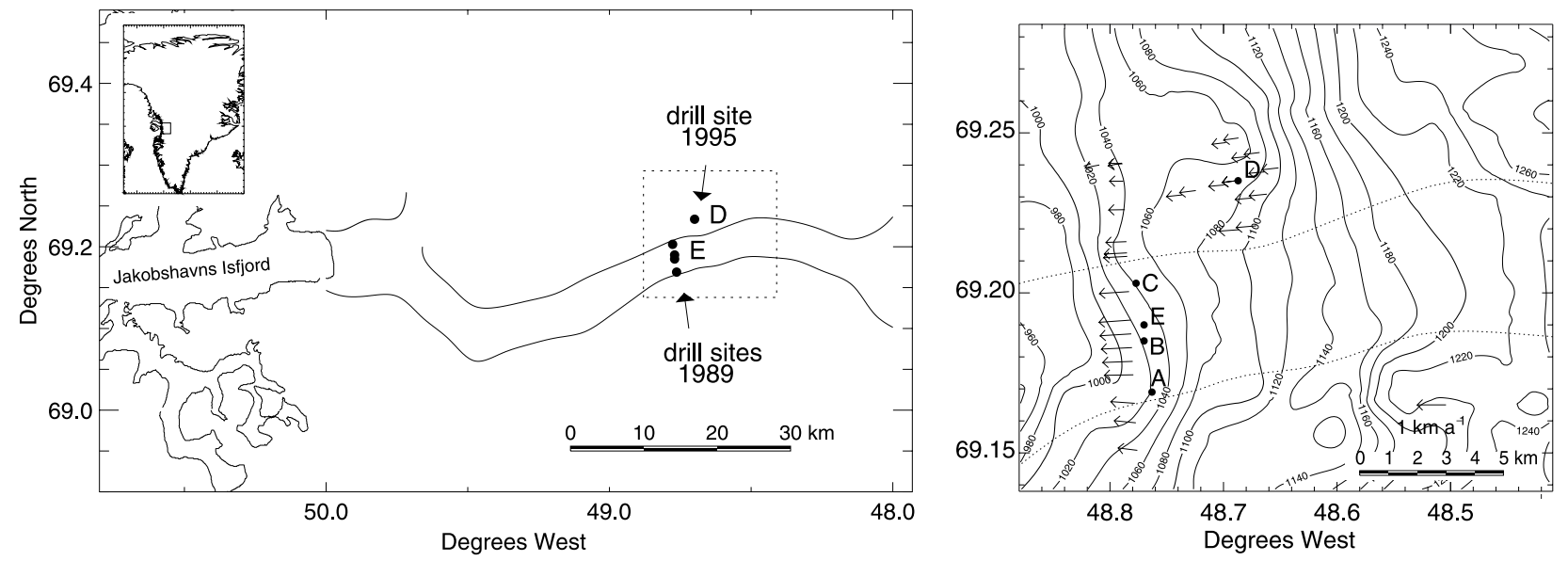

Fig. 1. Left: Location of the drill sites on Fakobshavn Isbre. The ice stream is indicated with solid lines inland of Jakobshavn Isfjord. The dotted frame is shown enlarged in the right plot. Right: The surface topography interpolated from laser altimeter data of NASA (see text for references). Contour lines are given in m a.s.l., and ice-stream margins are indicated with dotted lines. The 1989 ice-stream drill sites are indicated with dots and are labelled A-C (Iken and others, 1993). The new (1995) drill sites D and $E$ are located adjacent to the ice stream and in its centre. Velocities measured at stakes on the glacier surface are indicated along a transverse profile over the ice stream (Clarke and Echelmeyer, 1996) and around drill site D.

present in situ measurements in boreholes to the bed at a drill site adjacent to Jakobshavn Isbræ. The interpretation of the data is attempted with the help of a flow model, including heat conduction and advection and with a special emphasis on the correct treatment of the transition surface between the cold and the temperate zone.

As a test of the hypothesis of enhanced vertical extension of the basal ice in the ice stream, we attempt to trace certain englacial layers between the ice sheet and the ice stream. By comparing sequences of conductive layers in stream and sheet, it is possible to obtain information on the vertical extension which the ice in the stream has experienced relative to that in the sheet.

The following quantities of relevance to the dynamics of ice sheets and ice streams will be discussed in this study:

the englacial temperature distribution,

the thickness of the basal temperate layer,

the ice deformation and its variation with depth,

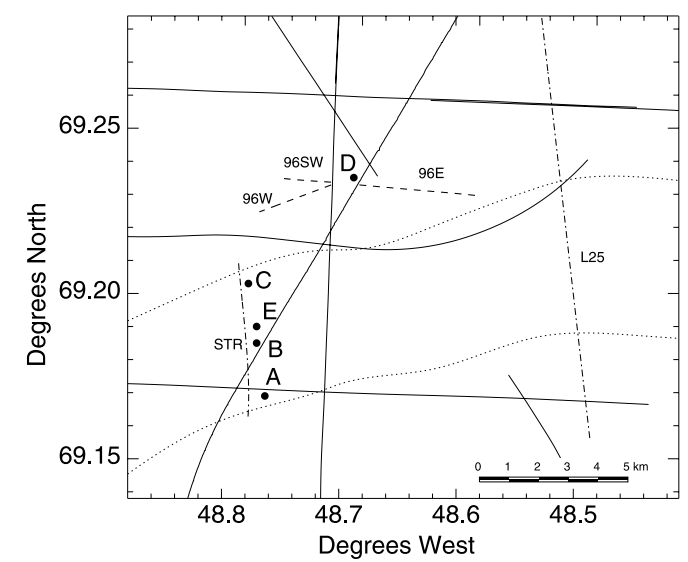

Fig. 2. Radar profiles recorded during the RSL/NASA flights are indicated with solid lines (RSL: Remote Sensing Laboratory of the University of Kansas). Dash-dotted lines indicate seismic soundings across the ice stream (STR and L25, Clarke and Echelmeyer, 1996), and dashed lines mark ground-based radar measurements during the 1996 field season (96W, 96SW and 96E). The ice-stream margins are indicated with dotted lines. the basal (sliding) velocity,

enhanced deformation of ice-age ice,

differences in vertical deformation history between the ice-sheet and the ice-stream drill sites,

an approximate dating of the ice,

the value of the Clausius-Clapeyron constant,

the water content of the ice at the cold-temperate transition surface (CTS) and

hydrological constraints on the nature of the subglacial drainage system.

This study is a contribution to the ongoing research effort on the mechanisms of fast flow of Jakobshavn Isbræ. It is a sequel to Iken and others (1993), further referenced as Part I, and Funk and others (1994), further referenced as Part II.

\section{FIELD OBSERVATIONS}

\subsection{Drill sites}

Two new drill sites were selected to provide field evidence complementary to that presented in Parts I and II (Iken and others, 1993; Funk and others, 1994). Site D is located at $69^{\circ} 14^{\prime} 6^{\prime \prime} \mathrm{N}, 48^{\circ} 41^{\prime} 13^{\prime \prime} \mathrm{W}, 4 \mathrm{~km}$ north of the ice-stream centre line and $5 \mathrm{~km}$ upstream of the 1989 drill sites. Surface velocities are about $600 \mathrm{ma}^{-1}$, the ice thickness is $830 \mathrm{~m}$ and the surface slope varies between $1^{\circ}$ and $2^{\circ}$. The new drill site $\mathrm{E}$ in the ice-stream centre was chosen close to the 1989 drill site B (Fig. 1).

The right plot of Figure 1 shows the surface elevation map interpolated from laser altimeter data recorded during the Airborne Topographic Mapper flights of NASA (Krabill and others, 1995; personal communication from W. Krabill, 1996). All available surface velocity measurements are also given (Fig. 4).

Ice thicknesses along profiles across the ice stream have been determined with the seismic method some kilometres from the drill site (Clarke and Echelmeyer, 1996). An extensive set of radar soundings has been measured with the airborne radar system of University of Kansas (Gogineni and 


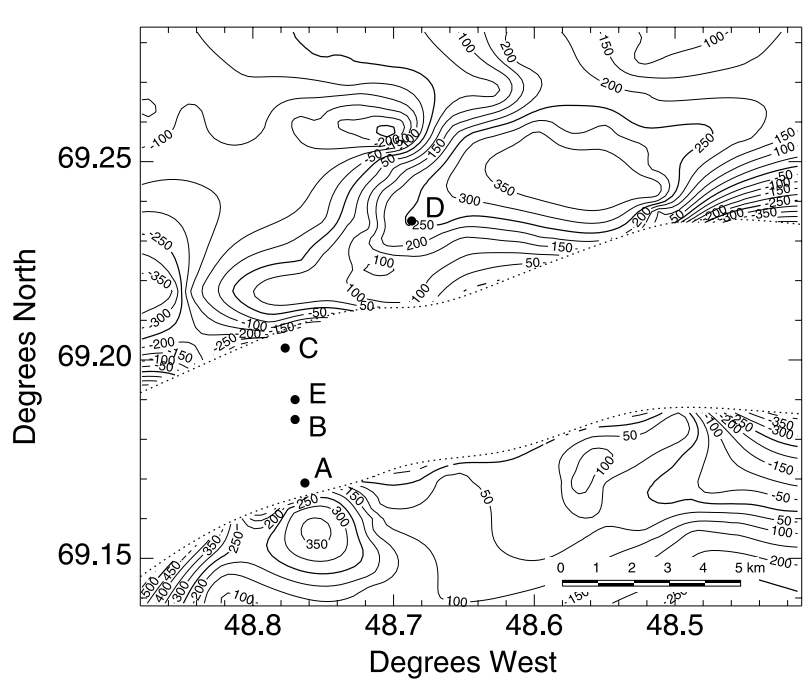

Fig. 3. Contour map of bedrock elevations derived from the seismic measurements and the radio-echo soundings in Figure 2. The approximate position of the ice-stream margins is indicated with dotted lines. Contour lines are drawn in $m$ a.s.l.

others, 1998). We performed complementary ground-based low-frequency radar measurements in June 1996 around drill site D (profiles 96W, 96SW and 96E in Fig. 2). The measured ice thickness at drill site D is about $830 \mathrm{~m}$, in excellent agreement with the borehole depths of $831 \pm 2 \mathrm{~m}$. The bedrock map (Fig. 3) results from the difference of the interpolated surface elevations and the ice thicknesses. Apparently drill site D is located on the downstream side of a long subglacial hill.

\subsection{Surface velocities}

Ice velocities were measured at drill site D and in its surroundings with a global positioning system (GPS Leica 200). The positions of a central marker at site D and of a network of stakes have been surveyed three to six times in 1995 and three times in 1996. The position accuracy is better than $\pm 0.03 \mathrm{~m}$ for differential measurements with short baseline (up to $4 \mathrm{~km}$ ) and $\pm 1 \mathrm{~m}$ for the single point solutions of the camp location.

The flow velocity calculated from the 1995 single point measurements is $623 \pm 20 \mathrm{~m} \mathrm{a}^{-1}$ with an uncertainty of the flow direction of $10^{\circ}$. In 1996 the surface velocity was $550 \pm 2 \mathrm{~m} \mathrm{a}^{-1}$, with a higher accuracy obtained with the differential GPS method with a reference station operated at Jakobshavn (some $100 \mathrm{~km}$ apart). The mean flow velocity calculated from the positions in 1995 and 1996 was $587 \pm 5 \mathrm{~m} \mathrm{a}^{-1}$. All absolute velocities are shown in Figure 1, together with velocities measured along the seismic profile STR (Clarke and Echelmeyer, 1996; personal communication from T. Clarke, 1998).

Displacements of eight stakes at a distance of $1-4.5 \mathrm{~km}$ were measured relative to drill site $\mathrm{D}$ with the differential GPS method. Mean strain rates at the drill site were calculated with a bilinear regression for each velocity component. The resulting principal strain rates are $\dot{\epsilon}_{1}=0.018-0.025 \mathrm{a}^{-1}$ (extensive) and $\dot{\epsilon}_{2}=-0.045 \mathrm{a}^{-1}$ (compressive). The direction of the principal compressive axis is $49^{\circ}$ (with respect to north, Fig. 4). The drill site is located in a region of shearing transverse to the mean ice flow (marked with a dotted line) which is caused by the lateral drag of the nearby ice stream. Hardly any variation in flow velocity was observed along the flow-

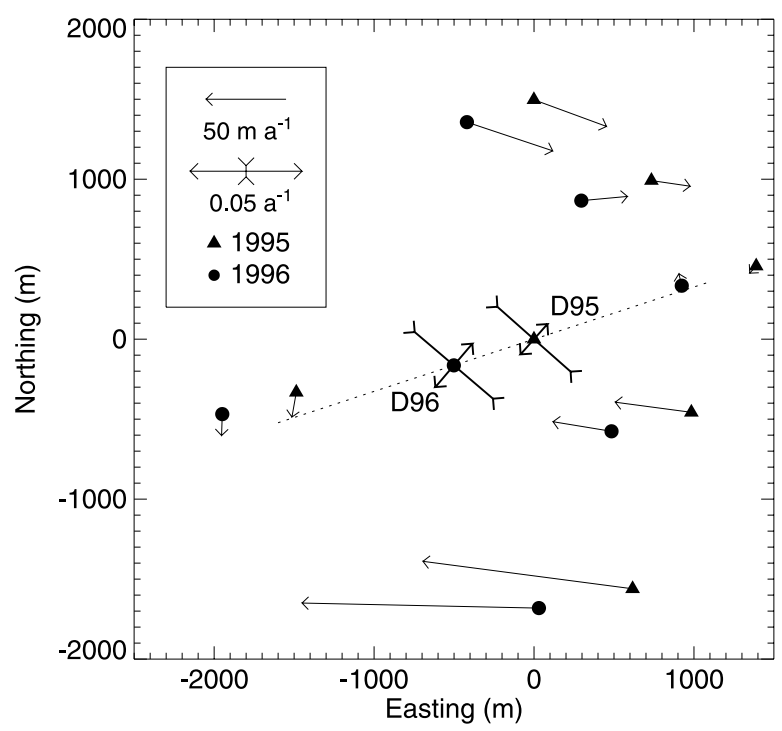

Fig. 4. Velocities of stakes relative to the reference station at drill site D. Coordinates are relative to the position of the drill site in 1995. Measurements from the 1995 field season are indicated with triangles, those of 1996 with dots. The principal axes of the mean strain rates are indicated with crossing arrows at the location of the drill site in 1995 (D95) and in 1996 (D96). Ice flow is from right to left along the dotted line with a mean velocity of $590 \mathrm{~m} \mathrm{a}^{-1}$. The ice-stream margin is $1 \mathrm{~km}$ south of the lowermost pole.

line. This indicates that the thickening of the ice is compensated by laterally convergent flow clearly visible in Figure 4.

\subsection{Drilling operation}

In July 1995 a total of eight holes were drilled at site D with the hot-water drilling system of VAW (Iken and others, 1989). At a constant discharge of $80 \mathrm{~L} \mathrm{~min}^{-1}$, the glacier bed at $830 \mathrm{~m}$ depth was reached within $6-8$ hours. The water immediately drained in all boreholes, and the borehole water level stabilized at the flotation level (see discussion in section 4.5). In August 1995 three $900 \mathrm{~m}$ deep holes were drilled at site $\mathrm{E}$ near the ice-stream centre line, where the ice thickness is about $2500 \mathrm{~m}$.

Five boreholes at site D were permanently instrumented with tilt sensors, thermistors and pressure cells which were measured with a specially devised telemetry system. (Details of the telemetry system, sensor calibration and the wiring are given in Appendix A.) In one borehole (marked "Electrode" in Fig. 5), a bare wire was frozen to the ice which served as a fixed common line electrode in the cross-borehole conductivity tests. All operations had to be accomplished within 2 hours after drilling, since the boreholes rapidly refreeze. The relative location of the eight boreholes with respect to the reference GPS station D95 is shown in Figure 5.

\subsection{Ice thickness at the drill site}

Direct measurements of the ice thickness at the drill site could be achieved with marked cables that were lowered into the boreholes. Due to the great depths, it was impossible to feel changes in cable tension as the weight at the lower end reached the bottom of the hole. Cross-borehole conductivity $(\mathrm{CBC})$ tests allowed determination of the bottom of the borehole, when the electric current measured between a moving electrode and the line electrode frozen into an adjacent borehole stabilized at a constant value. The elastic 


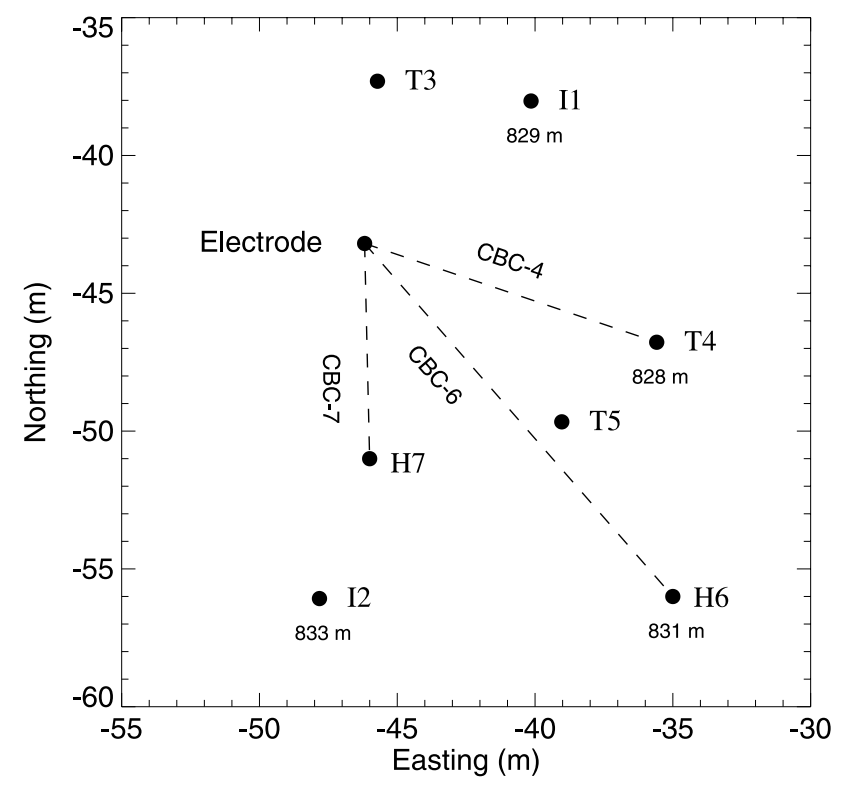

Fig. 5. The location of the boreholes at site $D$ is indicated with dots in a local coordinate system relative to the reference GPS station D95. Cables with thermistors were installed in boreholes T3- T5, tilt sensors, thermistors and pressure sensors in boreholes II and I2. One bare wire was frozen into the ice in the borehole labelled "Electrode". Cross-borehole conductivity $(C B C)$ tests were performed between the electrode and boreholes T4, H6 andH7 (labelled CBC-4, CBC-6 and CBC-7).

The borehole depths are indicated where measured.

stretching of the immersed electrode cable is $<0.1 \%$ and thus of the order $0.5 \mathrm{~m}$. Ice thicknesses determined with this method are between $828 \mathrm{~m}$ (hole T4) and $831 \mathrm{~m}$ (hole H6). Measurements in a borehole drilled at an angle of $3^{\circ}$ off the vertical would overestimate the ice thickness by about $1 \mathrm{~m}$. The ice thicknesses inferred from readings of the pressure cells are $829.4 \mathrm{~m}$ at $\mathrm{I} 1$ and $832.8 \mathrm{~m}$ at $\mathrm{I} 2$ with an accuracy of $\pm 1 \mathrm{~m}$. Both direct methods give ice thicknesses of 828$833 \mathrm{~m}$, in excellent agreement with the radar data. A slight dip of the bedrock in flow direction might be suspected from the data presented in Figure 5 and would agree with the large-scale topography.

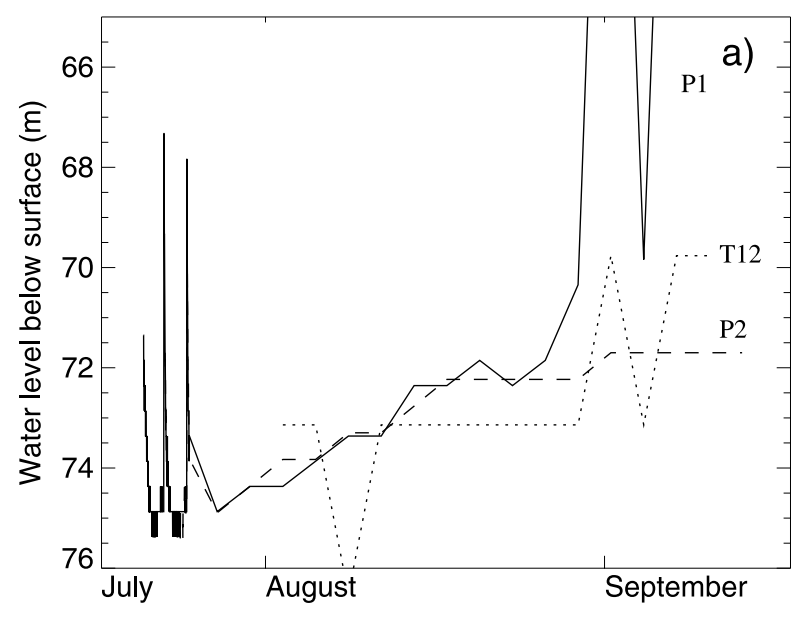

\subsection{Borehole water levels}

Water pressure was registered with two pressure sensors P1 and P2 installed at the bottom of boreholes Il and I2 (Fig. 6). No free water surface existed after refreezing of the boreholes some hours after installation of the instruments. Nevertheless, all readings are given in units of metres of water level below surface, since offset water levels measured with the float switch were corrected for in the data processing (see section 4.6.3 for a conversion to pressure).

Both water-level records are nearly identical until the end of August (Fig. 6a). Three peaks on 20, 22 and 24 July were caused by draining nearby boreholes, after drilling reached near bedrock (holes I1, I2 and H6 in Fig. 5). The rise of water level was very fast, followed by a slow decrease, until the initial water level was precisely recovered after 14 hours. A steady increase of $\sim 0.15 \mathrm{~m} \mathrm{~d}^{-1}$ water level was observed during August at both sensors. This is likely to be caused by the thickening of the overlying ice column as the instruments wander downslope from the subglacial hill (Fig. 3).

During the quiescent phases between two breakthrough events, small diurnal variations in basal pressure are visible in Figure 6b. The amplitude of these variations is $<1 \mathrm{~m}$ water level, but clearly follows a daily pattern with the lowest pressures recorded during the night.

The large pressure variation of $18 \mathrm{~m}$ water level $\left(1.8 \times 10^{5}\right.$ $\mathrm{Pa}$ ) registered at pressure sensor $\mathrm{Pl}$, starting on 29 August, would lower the freezing temperature by $0.014 \mathrm{~K}$. The fact that all thermistors near the bed in the same borehole show a temperature decrease of this order indicates that the registered event is not an artefact caused by an instrument error. Temperatures measured at thermistor T12 near the bed and converted to pressure (using the Clausius-Clapeyron equation (Equation (4)) of melting-point depression) are indicated with a dotted line in Figure 6a. The cable failed after the second large pressure increase on 10 September, and the cable of sensor P2 broke several days later. This sharp increase in pressure is likely to be caused either by some bedrock irregularity or by large water-pressure variations in the subglacial system. Such a pressure variation could occur when a lake at the ice surface suddenly drains through

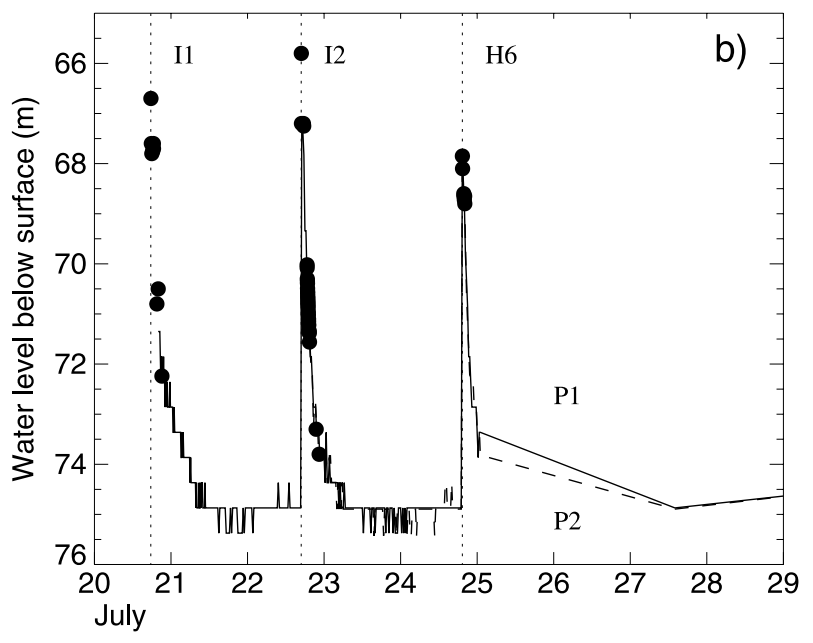

Fig. 6. (a) Water pressure was measured in two boreholes for nearly 2 months (curves P1 and P2). The initial spikes stem from breakthrough of neighbouring boreholes. A slow increase in water pressure is terminated by a large spike, prior to the rupture of the cables. The dotted line shows the temperature variation measured at thermistor T12, rescaled to water level with the dependence of melting temperature on pressure. (b) The water level stabilizes at the same depth after breakthrough of boreholes II, I2 and H6, marked with vertical dotted lines. Small diurnal variations of the pressure are also visible. Water levels below surface measured with the float switch are indicated with points. 

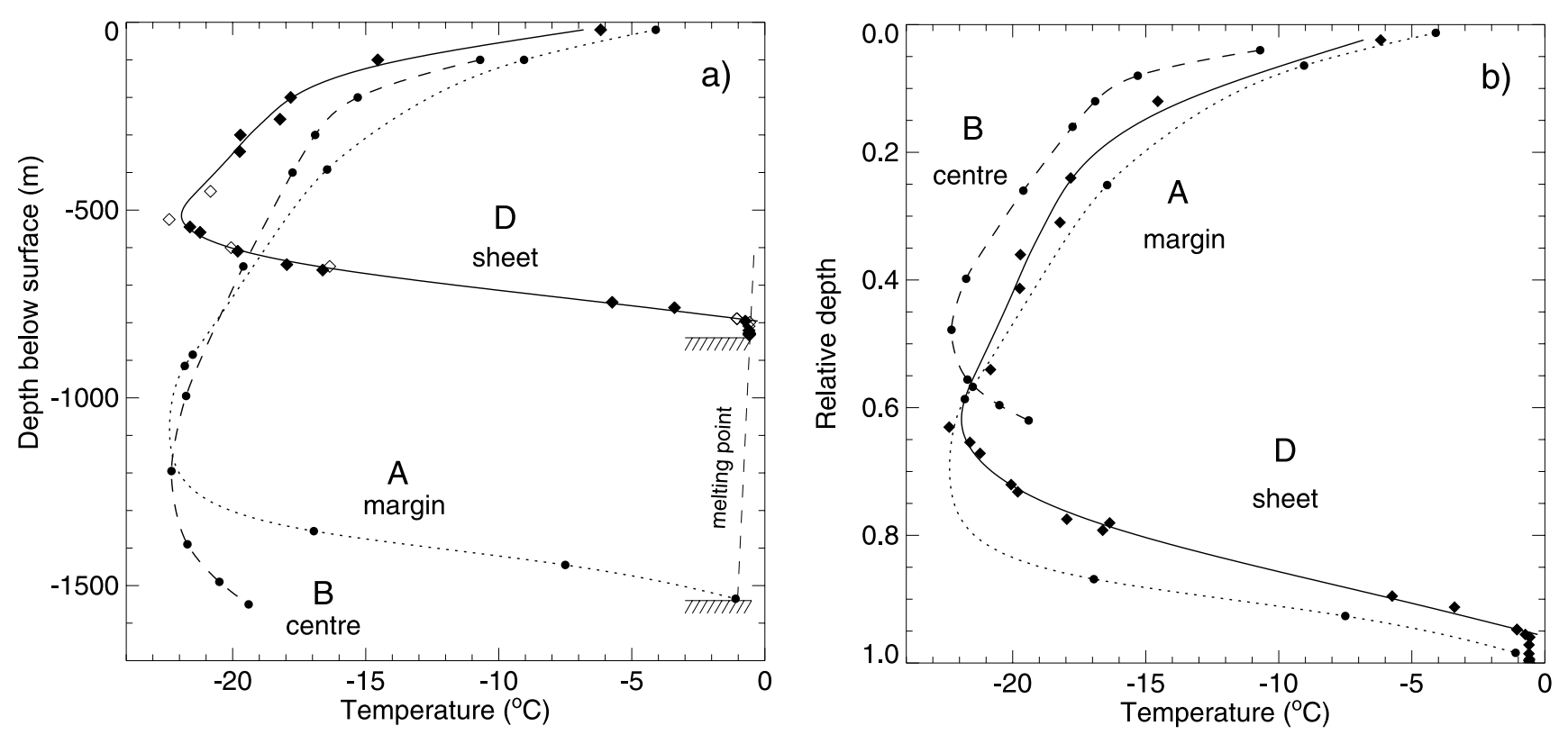

Fig. 7. Temperature profiles at ice-stream drill sites A (margin, dotted line) and B (centre, dashed line; data from Iken and others, 1993) and at the ice-sheet drill site D (solid line; see Fig. 1 for the location of the drill sites). The straight dashed line indicates the pressure-melting temperature. Depths are given in metres below the surface ( a) and on a relative depth scale ( $b$ ). The bedrock is indicated with a hatched area at drill sites A and D. Bedrock depth at the ice-stream centre line (borehole B) is approximately $2500 \mathrm{~m}$.

freshly opened, deep crevasses (Echelmeyer and Harrison, 1990), releasing huge amounts of water to the ice-sheet base.

\subsubsection{Discussion}

The equilibrium water level of $75.0 \pm 0.2 \mathrm{~m}$ below the surface corresponds to the flotation level at the ice thickness of $h_{\text {ice }}=$ $831 \pm 2 \mathrm{~m}$, if the average ice density is $\rho_{\text {ice }}=\left(h_{\mathrm{w}} / h_{\text {ice }}\right) \rho_{\mathrm{w}} \simeq$ $910 \mathrm{~kg} \mathrm{~m}^{-3}$, where $\rho_{\mathrm{w}}$ is the density of water at $0^{\circ} \mathrm{C}$. Assuming on the other hand an ice density of $917 \mathrm{~kg} \mathrm{~m}^{-3}$, a borehole water level of $68.8 \mathrm{~m}$ is calculated at floating equilibrium. In this case, the final borehole water levels of $75 \mathrm{~m}$ would correspond to an ice over-pressure of roughly $70 \mathrm{kPa}$.

Three pressure pulses propagated within 2 min to both pressure sensors at some tens of metres distance. Similar observations have been made on Trapridge Glacier (Stone and Clarke, 1993) and Ice Stream B (Whillans Ice Stream), Antarctica (Engelhardt and Kamb, 1997). Such fast pressure pulses require an active subglacial water system. The observation that the water level stabilized at the same value (at or nearly at overburden pressure) after each breakthrough event and in all boreholes excludes the existence of a large conduit passing near the drill site. Such a conduit would lower the water level below overburden pressure and would also drain the water away faster than observed.

The interpretation of the borehole water-level variations after breakthrough gives hydraulic transmissivities between $1 \times 10^{-5}$ and $1 \times 10^{-4} \mathrm{~m}^{2} \mathrm{~s}^{-1}$ (Lüthi, 1999). This corresponds to a homogeneous sediment layer of thickness $b=0.1-1 \mathrm{~m}$ and a hydraulic conductivity of $K_{\mathrm{s}} \sim 1 \times 10^{-3}$ to $1 \times 10^{-4} \mathrm{~m} \mathrm{~s}^{-1}$. This value compares well to the conductivity of a mediumsized sand found beneath many glaciers (Fischer and others, 1998). The alternative interpretation in terms of an open gap between the bottom of the ice and bedrock yields gap widths of $0.5-1 \mathrm{~mm}$.

We have no means to finally decide on the nature of the drainage system. The high observed basal velocities are consistent with both hypotheses. On the other hand, the storage capacities needed to absorb the initial water pulse $\left(\sim 7 \mathrm{~m}^{3}\right)$ after the breakthrough events, as well as the fast propagation of the pressure pulse to neighbouring boreholes, are readily explained with a system of gaps or linked cavities (Kamb, 1987).

\subsection{Englacial temperatures}

Englacial temperatures were measured with 29 temperature sensors installed in five boreholes at drill site D. Temperatures were recorded at a 3 day interval by data loggers at the surface until the cables failed due to overstretching. The asymptotic adjustment of borehole temperatures to the undisturbed ice temperature was accounted for in the data processing (Humphrey and Echelmeyer, 1990). The depths of the thermistors in holes I1 and I2 (see Fig. 5 for the location of the holes) are known to an absolute accuracy of $\pm 1 \mathrm{~m}$. The same accuracy is assumed for the thermistors in holes T4 and T5, as the elastic stretching of these cables is small. Thermistors 33 and 34 in hole T3 were caught at approximately $789 \mathrm{~m}$ depth which was inferred from the thermistor temperatures and the temperature profile measured in the adjacent holes.

\subsubsection{Comparison of temperature profiles}

The ice temperature profile measured at site $\mathrm{D}$ is shown in Figure 7. Temperature profiles from the ice-stream centre site $\mathrm{B}$ and site $\mathrm{A}$ at the southern margin are shown for comparison (Part I; see Fig. 1 for the location of the drill sites). The temperature profile from site D exhibits the same features as the profile from site A. Both profiles prove the existence of a basal layer of temperate ice and exhibit extremely high temperature gradients of $0.1-0.125 \mathrm{~K} \mathrm{~m}^{-1}$ above the temperate layer. The temperature minimum of about $-22^{\circ} \mathrm{C}$ and a marked bend of the temperature profile at about $200 \mathrm{~m}$ depth are common to all drill sites.

Measured temperatures are plotted on a relative depth scale $\bar{h}=h / H$ (where $h$ is the depth below surface and $H$ is the ice thickness) in Figure $7 \mathrm{~b}$. The profile from the icesheet site D lies between profiles A and B. The (inter- 


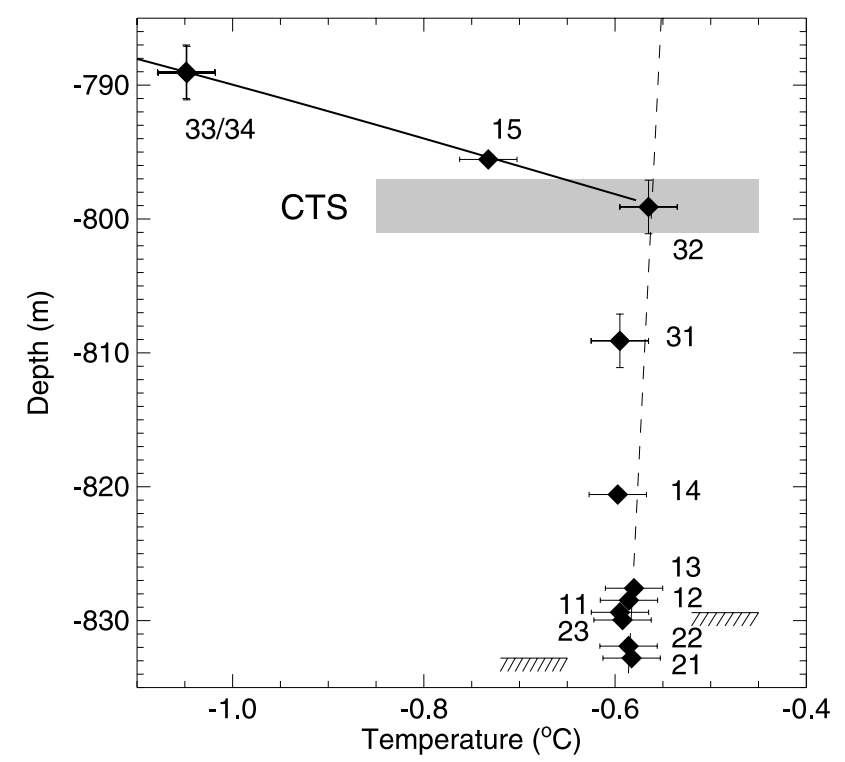

Fig. 8. Temperature vs depth near the base of the ice sheet. Measurements are shown with black diamonds, and thermistor numbers are indicated. The dashed line indicates the pressure-melting temperature, and hatched areas indicate the bedrock reached in two boreholes. The thickness of the temperate basal layer is $31 \pm 2 \mathrm{~m}$ (3.7 $\pm 0.3 \%$ of the ice thickness).

polated) temperature minimum of $-21.9 \pm 0.2^{\circ} \mathrm{C}$ is located at $535 \pm 10 \mathrm{~m}$ depth, corresponding to a relative depth of $\bar{h}\left(T_{\min }\right) \simeq 0.65$, whereas it is at 0.43 at the ice-stream centre $\mathrm{B}$ and at 0.7 at site $\mathrm{A}$.

\subsubsection{Phase transition boundary (CTS)}

The ice temperatures near the base at site D are shown in Figure 8. The CTS (indicated with a grey bar) is located at $799 \pm 2$ m depth below the surface. The thickness of the temperate basal layer therefore is $31 \pm 2 \mathrm{~m}$ and corresponds to $3.7 \pm 0.3 \%$ of the ice thickness of $831 \pm 2 \mathrm{~m}$.

The CTS is defined as a singular surface where the moisture content and the temperature gradient may experience a finite jump (Hutter, 1993). This idealized transition surface will be somewhat fuzzy in reality, since water in veins and lenses is under different pressures, and melting temperature varies accordingly on the scale of ice grains (Lliboutry, 1993). The measurements presented in Figure 8 show that this possible gradual transition is confined to within $2 \mathrm{~m}$, and that the concept of the CTS as a singular phase transition surface is well justified. (Similar observations have been made on Hansbreen, Svalbard (Jania and others, 1996).

The abrupt change of the temperature profile at the CTS is indicative of a freezing condition which manifests itself by a discontinuous temperature gradient (Blatter and Hutter, 1991; Hutter, 1993). Assuming therefore an ice flux from the temperate into the cold region, the unfrozen moisture content multiplied with the ice flux across the CTS can be readily calculated. The derivative of the interpolated temperature with respect to the vertical coordinate at the CTS is $\partial T / \partial z=-0.048 \pm 0.01 \mathrm{~K} \mathrm{~m}^{-1}$. The total heat released by the refreezing water per unit time and unit area of the CTS is (in the notation of Part II)

$$
\dot{Q}_{\mathrm{L}}=\mu \Xi \rho_{\mathrm{w}} L,
$$

where $\mu$ is the water content of the temperate ice, $L$ is the latent heat of freezing, $\rho_{\mathrm{w}}$ is the density of water and $\Xi$ is the upward flux of ice through an element of the CTS. The temperature gradients $\partial T / \partial z$ and $\beta$ above and below the CTS are related by

$$
-\left.\frac{\partial T}{\partial z}\right|_{\mathrm{CTS}}=\frac{\dot{Q}_{\mathrm{L}}}{k}-\beta,
$$

where $k=2.1 \mathrm{~W} \mathrm{~m}^{-1} \mathrm{~K}^{-1}$ is the thermal conductivity of ice. Inserting Equation (1) into the above relation yields the product of the moisture content and the mass flux through the phase transition surface

$$
\begin{aligned}
\mu \Xi & =\frac{k}{\rho_{\mathrm{w}} L}\left(\beta-\left.\frac{\partial T}{\partial z}\right|_{\mathrm{CTS}}\right)=3.02 \times 10^{-10} \mathrm{~m} \mathrm{~s}^{-1} \\
& =0.0095 \mathrm{~m} \mathrm{a}^{-1}
\end{aligned}
$$

Conventionally, a maximum water content of $1 \%$ is assumed in temperate ice. This is based on observations in ice cores in Alpine glaciers at depths up to $250 \mathrm{~m}$ (Vallon and others, 1976; Lliboutry and Duval, 1985; Lliboutry, 1993). Assuming this value, the velocity of the ice with respect to the CTS would be of the order $\Xi \sim 1 \mathrm{~m} \mathrm{a}^{-1}$. The above result makes it possible to determine the water content of the basal ice when $\Xi$ is known. This will be accomplished with a flow model in section 5.3.

\subsubsection{Melting-point depression}

The depression of the melting-point temperature $T_{\mathrm{m}}$ of pure ice with absolute pressure $p$ is described by

$$
T_{\mathrm{m}}=T_{\mathrm{tr}}-\gamma\left(p-p_{\mathrm{tr}}\right),
$$

where $T_{\mathrm{tr}}=273.16 \mathrm{~K}$ and $p_{\mathrm{tr}}=611.73 \mathrm{~Pa}$ are the triple-point temperature and pressure of water and $\gamma$ is the ClausiusClapeyron constant. This equation is used in thermomechanically coupled flow models of polythermal ice sheets in order to determine the thickness of the temperate basal layer. Usually values between $\gamma=0.0742 \mathrm{~K} \mathrm{MPa}^{-1}$ for pure ice and air-free water (Paterson, 1994) and $\gamma=0.098 \mathrm{~K} \mathrm{MPa}^{-1}$ for airsaturated water are used (Harrison, 1972; Lliboutry, 1993). Several modelling studies use an intermediate value of $\gamma=$ $0.087 \mathrm{~K} \mathrm{MPa}^{-1}$ (e.g. Greve and Hutter, 1995; Huybrechts and others, 1996). However, there is no direct evidence for the assumption of this value from measurements in deep boreholes in ice sheets.

The borehole temperatures measured in the basal temperate layer at site $\mathrm{D}$ are between $-0.60^{\circ}$ and $-0.56^{\circ} \mathrm{C}$ (Table 1 ). The conversion of depth below the surface to pressure is accomplished with the local gravity acceleration $g=$ $9.825 \mathrm{~m} \mathrm{~s}^{-2}$ (personal communication from R. Forsberg, 1999) and the density of water $\rho_{\mathrm{w}}=999.841 \mathrm{~kg} \mathrm{~m}^{-3}$ at $0^{\circ} \mathrm{C}$ (neglecting the compressibility of water). The equilibrium water level in the open boreholes is $75.0 \pm 0.2 \mathrm{~m}$ below the surface. Thus at $831 \mathrm{~m}$ depth the absolute hydrostatic pressure is $p_{\mathrm{a}}+7.4265 \mathrm{MPa}$ where the atmospheric pressure $p_{\mathrm{a}}$ is about $0.089 \mathrm{MPa}$. The accuracy of the data is not good enough to determine the Clausius-Clapeyron constant from the measurements alone. In order to calculate a regression curve, we add the triple point of water. The ClausiusClapeyron constant then is $\gamma=0.079 \pm 0.002 \mathrm{~K} \mathrm{MPa}^{-1}$ which is within the values of previous observations. This value is indicative of a low content of soluble impurities and air in the basal ice. 

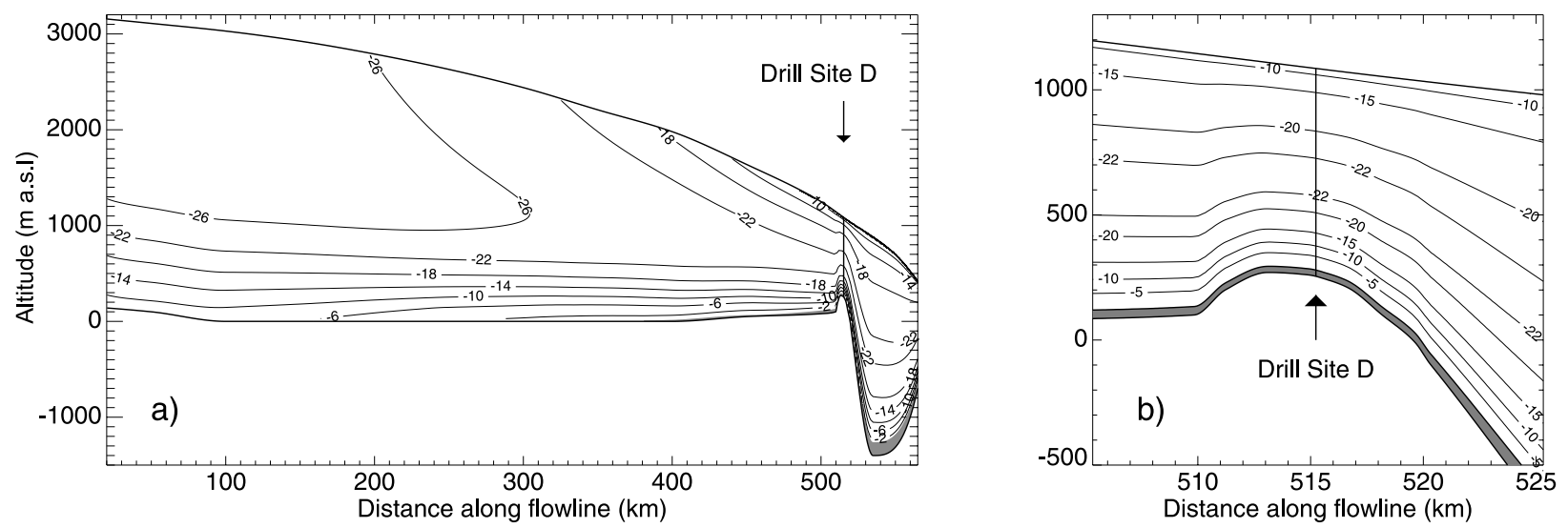

Fig. 9. (a) Modelled temperature distribution along a flowline passing through drill site D, marked with an arrow. ( $b$ ) An enlarged view of the surroundings of site $D$. The temperate layer is indicated with a shaded area. Note that the vertical scale is greatly exaggerated.

\section{MODEL GALGULATIONS}

A model for the calculation of the two-dimensional temperature field as well as the ice-flow velocity has been developed in Part II (Funk and others, 1994) and was successfully applied to the interpretation of temperature profiles measured in Jakobshavn Isbræ. The velocity profile is calculated with Glen's flow law, consistent with the surface velocities and the ratio of basal motion prescribed as model input. Further assumptions are a linear variation of shear stress with depth (i.e. the longitudinal stress gradient is independent of depth), small surface and bed slopes and a negligible transverse shear stress. The continuity is accounted for by transverse straining, and the azimuth of ice flow is assumed not to vary with depth. These assumptions are justified for ice-sheet flow but are expected to fail if the flow pattern is complicated as in the zone of ice-stream formation. The heat-flow model includes conduction and advection in two dimensions and heat generation due to dissipation. Special attention has been paid to the correct treatment of the phase boundary and the evolution of a basal temperate layer. Technically the model is implemented with the finite-difference method, and heat advection is treated with a moving-column model. The model assumptions and the implementation are described in detail in Part II which was improved to include basal melting.

\subsection{Model input}

The model was run with basically the same input data as the original model of Part II. The bedrock and the surface topographies were adapted to the local topography around the ice-sheet drill site D (Figs 1 and 3). The subglacial hill where the drill site is located is taken into account as well as the measured surface topography along an approximate flowline passing through the drill site. The geometry along the flowline starting at the ice divide is shown in Figure 9.

The ice-flow law (Glen's flow law) has been used in the form $\dot{\epsilon}_{i j}=A_{0} B(T) \tau^{n-1} \sigma_{i j}^{\prime}$ ( $\sigma_{i j}^{\prime}$ is the deviatoric stress tensor and $\left.\tau^{2}=(1 / 2) \sigma_{i j}^{\prime} \sigma_{i j}^{\prime}\right)$. The temperature dependence $B(T)$ is factored out (Smith and Morland, 1981) and flow-law parameters $A_{0}=2.85 \times 10^{-16} \mathrm{kPa}^{-2} \mathrm{~s}^{-1}\left(\right.$ at $\left.0^{\circ} \mathrm{C}\right)$ and $n=2$ have been used (see Part II for a discussion of these values).

In order to assess the influence of model input quantities that are not accurately known, a reference model run will be compared to results from model runs with altered parameters. The surface velocity measured at the drill site and at a nearby seismic profile (STR in Fig. 2) are prescribed. The ratio of basal motion, defined as the contribution of basal velocity to the surface velocity, was estimated from borehole deformation measurements and amounts to about $60 \%$ at the drill site (section 6.1.3). The input for the reference model is shown in Figure 10a (solid line); input quantities of the

Table 1. Temperatures measured in five boreholes in the ice sheet adjacent to Jakobshavn Isbre

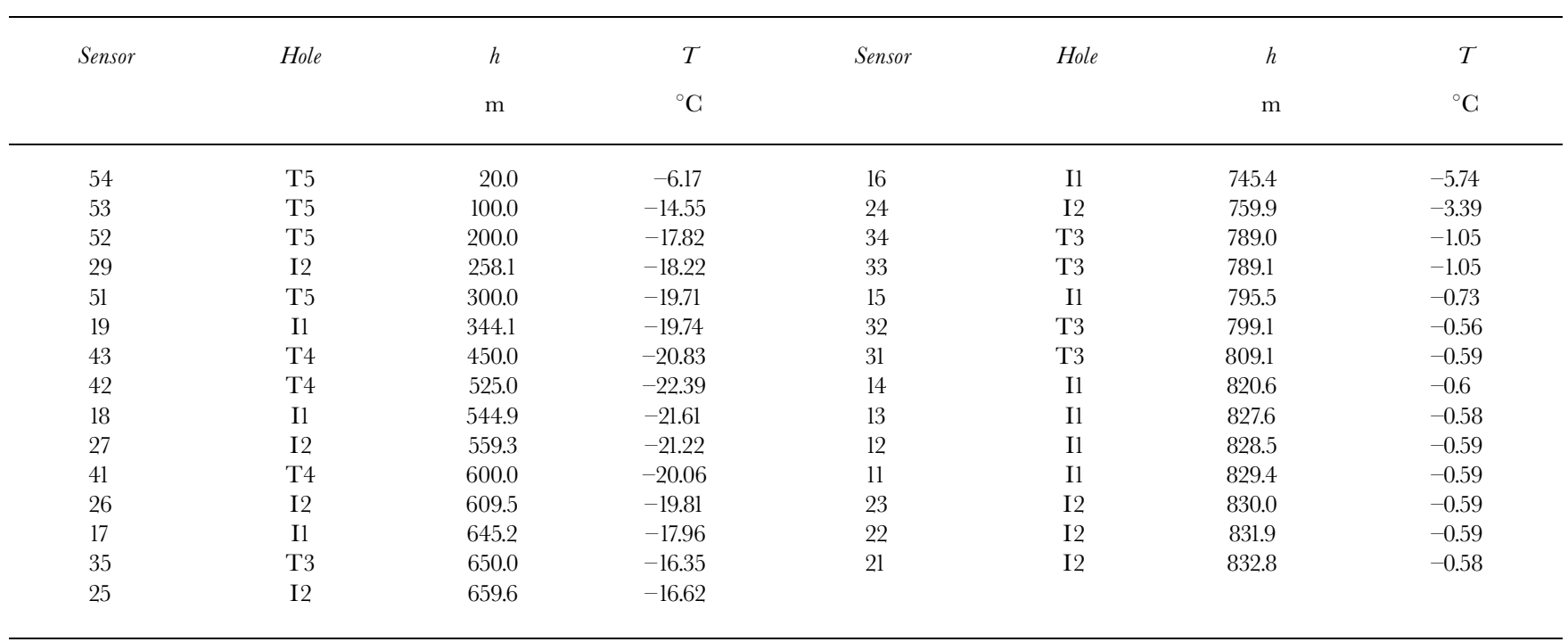

Note: The local ice thickness is $831 \pm 2 \mathrm{~m}$, the depths are accurate to $\pm 1 \mathrm{~m}$ and the accuracy of the temperatures is $\pm 0.03^{\circ} \mathrm{C}$ near $0{ }^{\circ} \mathrm{C}$ and $\pm 0.05^{\circ} \mathrm{C}$ at low temperatures. 

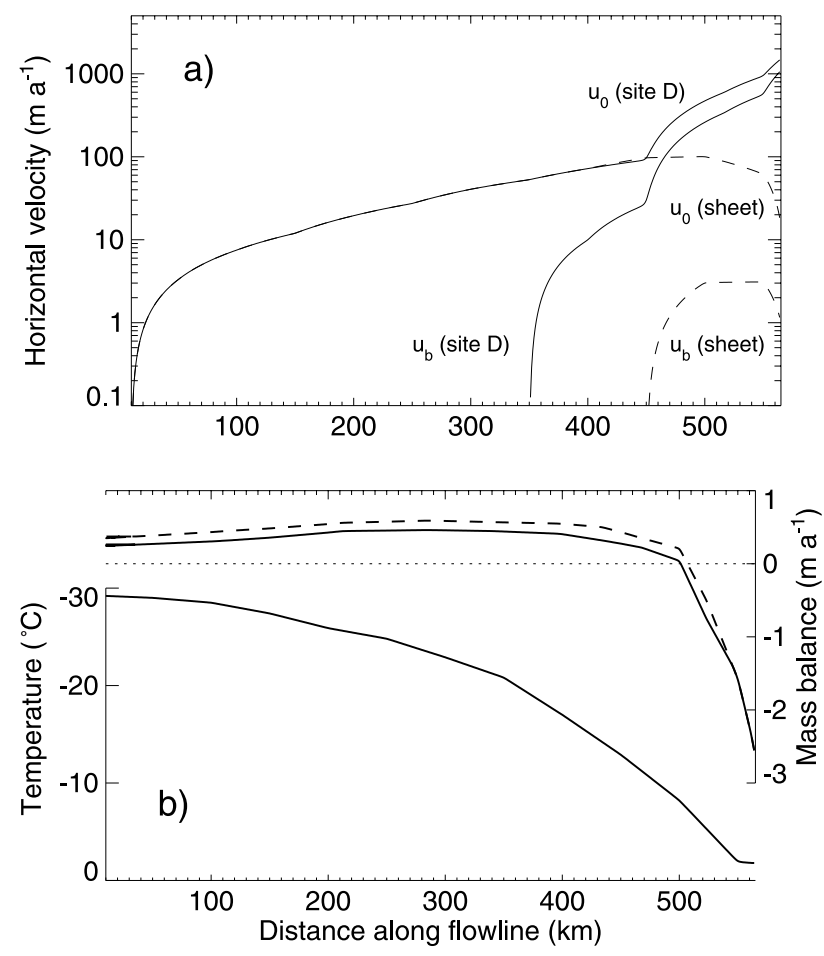

Fig. 10. (a) Prescribed values of horizontal velocity us distance along a flowline. The velocity values of the flowline passing through site $D$ are shown with a solid line, those of the plain ice-sheet model (Part II) with a dashed line. $u_{0}$ is the surface velocity, $u_{\mathrm{b}}$ the basal velocity. (b) The prescribed mass balance for the reference run is drawn with a solid line, an enhanced accumulation rate with a dashed line (upper panel) and the surface temperature is given in the lower panel. The drill site is located at $515 \mathrm{~km}$.

plain ice-sheet model (Part II; dashed line) are plotted for comparison. The mass balance and the surface temperature are the same as in the previous study (Fig. 10b).

\subsection{Modelled temperatures}

The modelled temperature distribution along the flowline passing through drill site D is shown in Figure 9. A basal

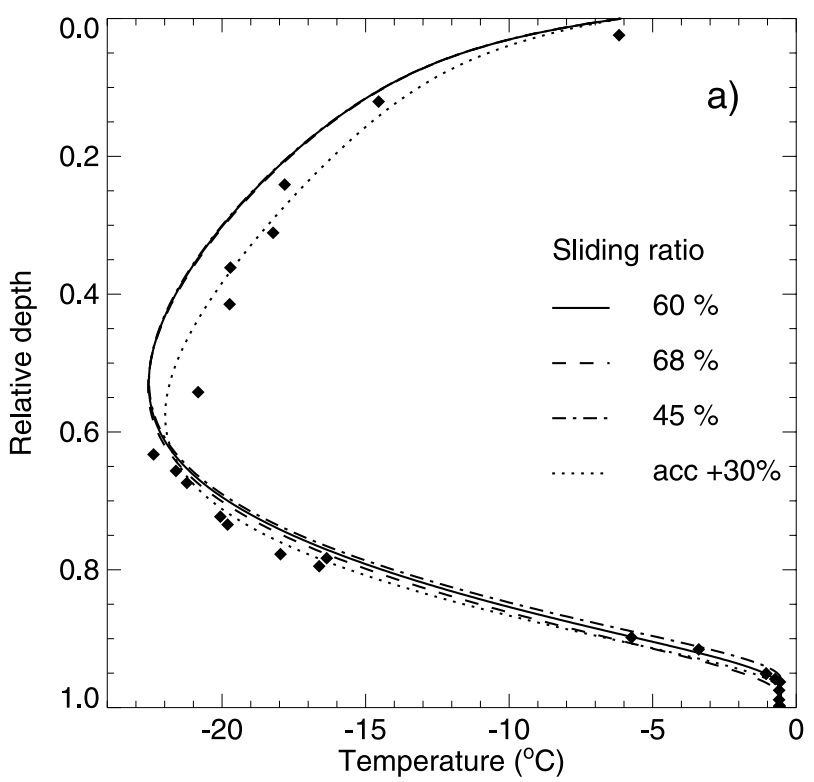

temperate layer forms at the horizontal distance of $400 \mathrm{~km}$ from the ice divide and reaches some tens of metres thickness at the drill site $(515 \mathrm{~km}$ from the ice divide). The bedrock hill has a major influence on the temperature distribution (right plot of Fig. 9).

The modelled temperature profile at the drill site is shown in Fig. 11. The agreement of the reference model (solid line) with the measurements is remarkable for both the thickness of the temperate layer and the high temperature gradient near the base. Nevertheless, some important differences exist. The temperature minimum at a relative depth of 0.5 is $-22.5^{\circ} \mathrm{C}$, whereas the measured minimum is about $1^{\circ} \mathrm{C}$ higher and is located at a relative depth of 0.6 . Also the near-surface temperatures are slightly too low, which could easily be accounted for by altering the prescribed surface temperature distribution. The effect of crevasses filled with meltwater is likely to contribute to increased near-surface temperatures (Part I).

The ratio of basal motion has a minor influence on the temperature profile and mainly affects the depth of the CTS and the temperature gradient above the CTS (Fig. 11b). It has been shown in Part II that the location of the temperature minimum depends mainly on the accumulation rate controlling the vertical advection. The dotted line in Figure 11 was obtained with an accumulation rate increased by roughly $30 \%$ (dashed line in Fig. 10) at a basal motion ratio of $60 \%$. The resulting temperature profile closely matches the measured profile, depressing the relative position of the temperature minimum to 0.6 and leading to a larger temperature gradient above the CTS. The minimum temperature is $-21.9^{\circ} \mathrm{C}$, in good agreement with the measurements.

This observation raises some doubts concerning the assumption that the mass-balance measurements from the EGIG (Expéditions Glaciologiques Internationales au Groenland) line (located some $80 \mathrm{~km}$ north of the ice stream) can be extrapolated to the Jakobshavn basin (Ohmura and Reeh, 1991). Mass balance has never been measured in large parts of the Jakobshavn accumulation area, and the model input is based on an interpolation (personal communication from A. Ohmura, 1994). Echelmeyer and others (1992) measured an accumulation rate in the ice-stream region which

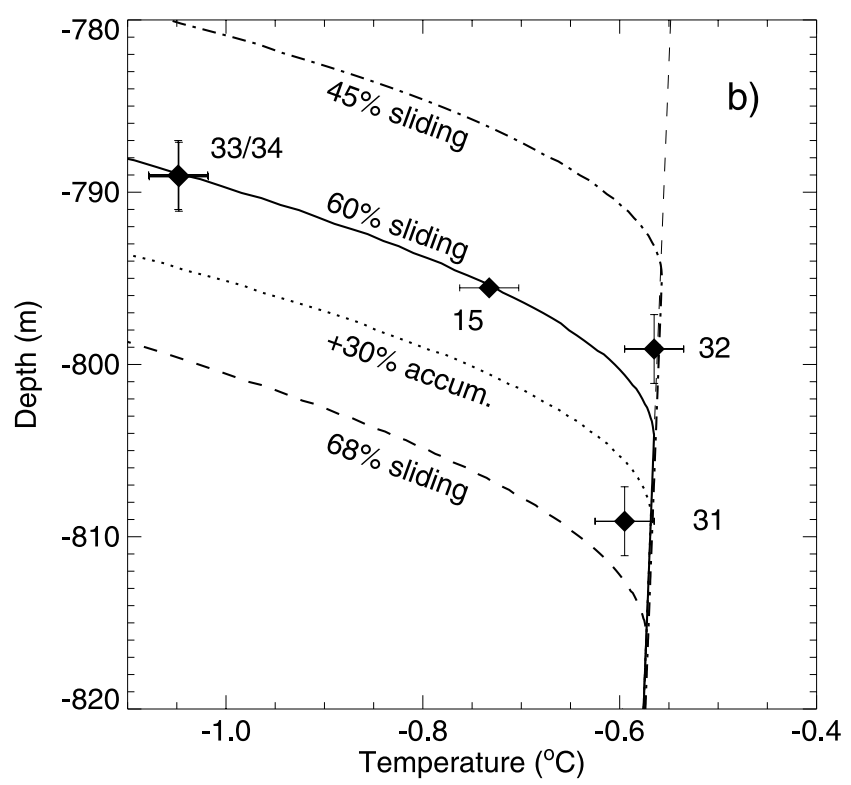

Fig. 11. (a) Modelled temperature profiles at site D for zero water content of the temperate ice. The influence of different basal motion ratios and an increase in accumulation rate at a constant basal motion ratio of $60 \%$ are shown. Measured temperatures are indicated with black diamonds. (b) An enlarged view of the zone near the CTS. 


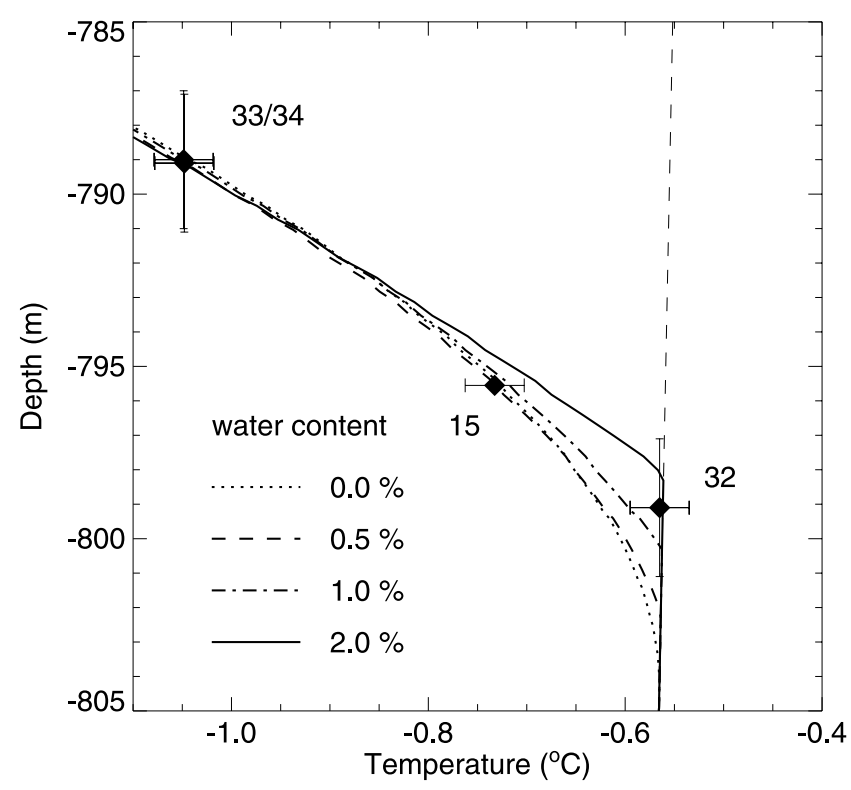

Fig. 12. Modelled temperatures at the position of the CTS for different moisture contents of the ice at the CTS. Comparison with temperatures measured at thermistors (indicated with diamonds and the respective error bars) suggests a moisture content of about $1 \%$.

was 30-40\% lower than at the EGIG line. In contrast, the best agreement with modelled temperatures was obtained with an accumulation rate increased by roughly $30 \%$ with respect to the EGIG values in the upper part of the ice sheet. A possible explanation for these inconsistencies is that accumulation rates have been higher in the past and/or that the surface elevation of the Jakobshavn basin has changed considerably. An alternative explanation for at least part of this discrepancy is the result of the modelling study of the ice stream, showing that taking into account the climate history since the last ice age in a transient model run results in a lower position of the temperature minimum (Funk and others, 1994, figs 8 and 10).

\subsection{Water content of the ice at the CTS}

The model predicts a temperate layer of almost exactly the thickness measured in the boreholes at site D. In accordance with the interpretation of the measured temperatures at the CTS (section 4.6.2), a freezing condition at the CTS is calculated by the model. Thus the temperature profile just above the CTS as well as the vertical position of the CTS depend on the water content of the ice traversing the boundary from the temperate into the cold region. An evaluation of the measured temperature gradient just above the CTS (section 4.6.2) resulted in the product of water content times ice velocity through the CTS of $\Xi \mu \sim 0.01 \mathrm{~m} \mathrm{a}^{-1}$.

Calculated temperatures near the CTS are compared to temperatures measured at three thermistors in Figure 12 for water contents of the ice in the range $\mu=0-2 \%$ and a ratio of basal motion of $60 \%$. A very good agreement with the measured temperatures is obtained with a water content of $1.0-1.5 \%$. The inaccurate absolute vertical position of thermistors 32 and 33 prevents a precise evaluation of the data. Nevertheless, their maximal vertical spacing of $10 \mathrm{~m}$ gives an additional constraint and we therefore exclude a moisture content $<0.5 \%$.

\subsection{Discussion}

The good agreement of measured and modelled CTS locations indicates that the model incorporates all relevant physical processes along the flowline passing through the ice-sheet site D. The minor ambiguities in the precise location of the temperature minimum and its absolute value are within the expected uncertainties caused by an inaccurate model input.

On the other hand, the mismatch of the modelled temperatures with profiles measured at the ice-stream centre location B and at the marginal location A (Fig. 1) could not be accounted for by varying the model input (Fabri and others, 1992). These findings corroborate the conclusion that the form of the temperature profiles at the ice-stream sites is caused by additional deformation processes associated with the convergent flow into the ice stream. The three-dimensional flow field and the extra vertical stretching of the basal ice proposed in Parts I and II are likely to account for this mismatch. Further evidence for these conclusions is given in the next section.

\section{ICE DEFORMATION}

Two sets of ice-deformation measurements are presented in this section. The progressive deformation of two boreholes at site $\mathrm{D}$ has been recorded with tilt sensors frozen to the ice. This allows us to calculate the ice-deformation velocity and to infer the basal (sliding) velocity. High ice-deformation rates have been observed in the lowermost $160 \mathrm{~m}$. With the help of in situ electrical conductivity measurements (ECM) (section 6.2.1) we assign this ice to the Wisconsin (ice-age) period. Comparison of conductivity logs at sites $\mathrm{D}$ and $\mathrm{E}$ provides information on the different ice-deformation histories in sheet and stream. From these we draw conclusions on the mechanics of the ice-stream formation.

\subsection{Borehole deformation measurements}

Two boreholes at drill site $\mathrm{D}$, separated by some $20 \mathrm{~m}$ at the surface, were instrumented with a total of 17 tilt sensors. The sensors are labelled I11-I19 (in borehole I1, Fig. 5) and I21I27 and I29 (in borehole I2). The wiring, the depths of the sensors and the calibration are discussed in Appendix A. Tilt angles were registered for 50-300 days until the respective cable sections failed due to overstretching. Plots of the individual tilt sensor measurements are presented in Appendix B.

\subsubsection{Interpretation in terms of simple shear}

Simple shear is the dominant contribution to the ice deformation at drill site D. Minor additional strain rates are expected as the ice thickens in the flow direction, and lateral convergence and shearing have been observed at the surface (section 4.2). Despite the fact that considerable basal motion takes place, almost no longitudinal extension was observed around the drill site. Close to the bedrock, additional complications enter through the polythermal structure of the ice, the small-scale bedrock topography, spatially varying basal motion influenced by an unknown sliding law and the different rheology of the ice near the bed. Despite these intricate difficulties, a simplified interpretation in terms of simple shear seems to be justified.

Under simple shear, all velocity components are constant except the horizontal velocity $u$ which varies with depth. The measured tilt rates were fitted using an optimiza- 

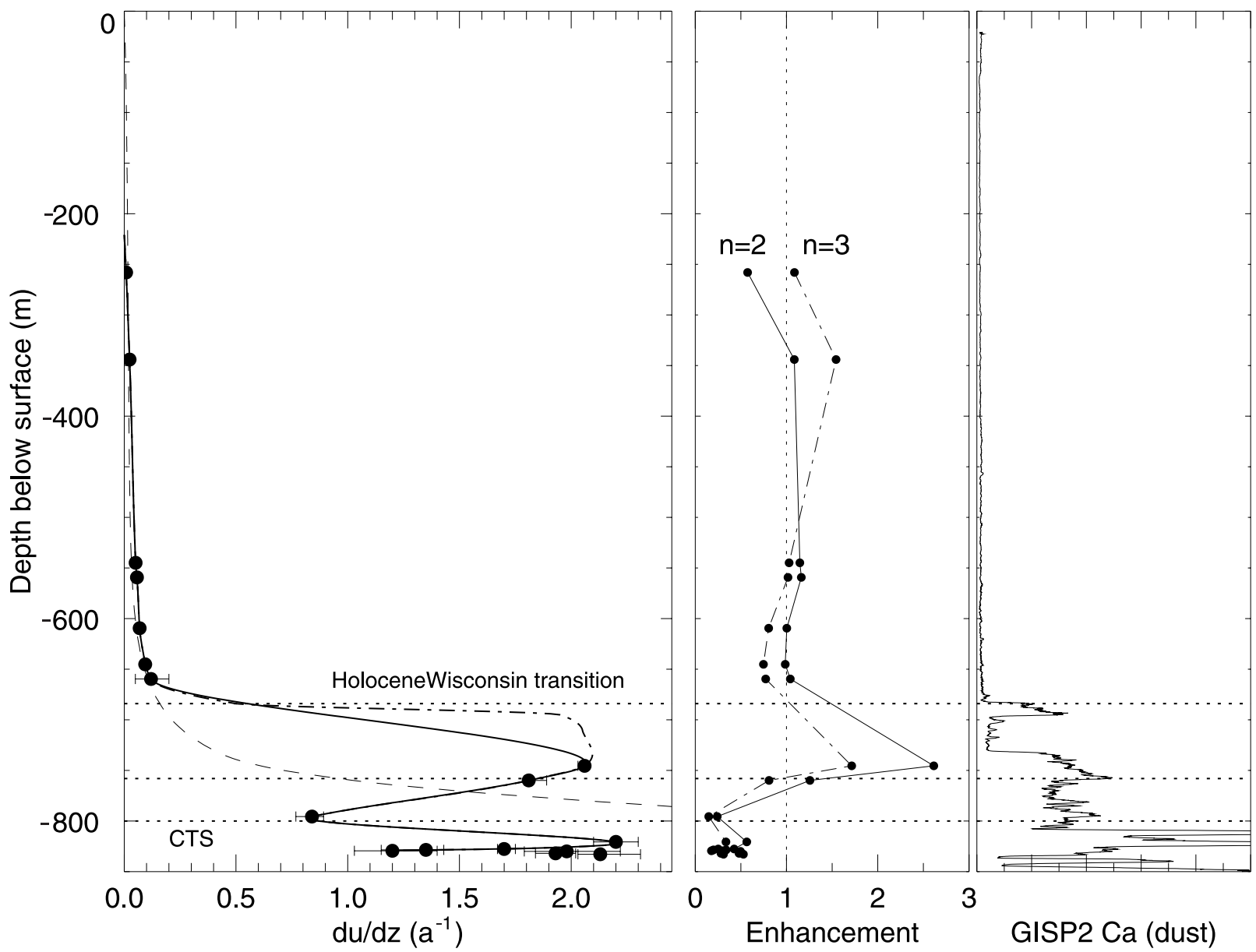

Fig. 13. Left: Vertical gradients of horizontal velocity $\partial u / \partial z$ measured at site $D$ are indicated with dots and error bars. Integrating the velocity gradients interpolated with the solid line gives a surface velocity due to deformation of $235 \mathrm{ma}^{-1}$. The alternative interpolation gives $260 \mathrm{~m} \mathrm{a}^{-1}$ (dash-dotted line). At a measured surface velocity of $620 \mathrm{~m} a^{-1}$ the ratios of basal motion are $63 \%$ and $57 \%$. The Holocene-Wisconsin transition as well as the CTS are indicated with dotted lines. Modelled deformation rates are indicated with a dashed line. Middle: The enhancement factor for flow-law parameters $n=2$ and $n=3$. Right: Calcium dust measured on the GISP2 core (data from Mayewski and others, 1997; see text for details).

Table 2. Velocity gradients measured at 17 tilt sensors in drillholes II and I2. The maximal deviation of the fitting function is given in the fourth column. $E_{2}$ and $E_{3}$ are the enhancement factors calculated for $n=2$ and $n=3$

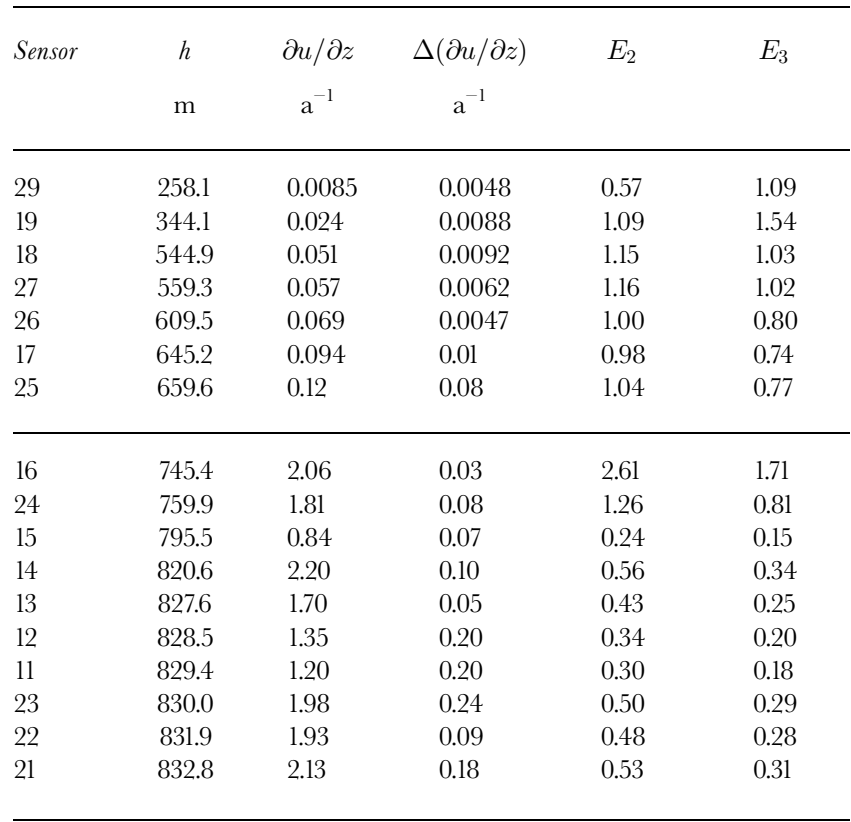

Note: The transition to the Wisconsin ice is below sensor 25 (marked with a line) tion procedure, in which the vertical gradient of horizontal velocity, the initial inclination angle and the initial azimuth angle (with respect to the flow direction) were varied as free parameters. Resulting velocity gradients $\partial u / \partial z=2 \dot{\epsilon}_{x z}$ are given in Table 2, together with the maximal deviation $\Delta \partial u / \partial z$ from the fitting curve.

The vertical gradients of horizontal velocity $\partial u / \partial z$ are plotted vs depth below the surface in Figure 13. Strain rates increase by an order of magnitude below $680 \mathrm{~m}$ depth, decrease at $800 \mathrm{~m}$ and increase again within the temperate zone below the CTS. Vertical velocity gradients calculated with the flow model show a good agreement with the measurements down to $660 \mathrm{~m}$ depth (dashed line in Fig. 13).

\subsubsection{Flow enhancement}

The flow model (section 5) predicts that ice below $680 \mathrm{~m}$ depth is of pre-Holocene (ice-age) origin. Such ice sometimes deforms at much higher rates than ice from the Holocene era (Paterson, 1991). Indeed, all tilt sensors below $680 \mathrm{~m}$ depth exhibit high tilt rates (Table 2; Fig. 13). It is convenient to express the observed deformation rates in terms of an enhancement factor $E$ with respect to the deformation rate calculated with Glen's flow law (written as $\dot{\epsilon}_{i j}=A_{0} B(T) \tau^{n-1} \sigma_{i j}^{\prime}$, where $A_{0}$ and $n$ are flow-law parameters and $B(T)$ absorbs the temperature dependence). Assuming simple shear, the stress invar- 


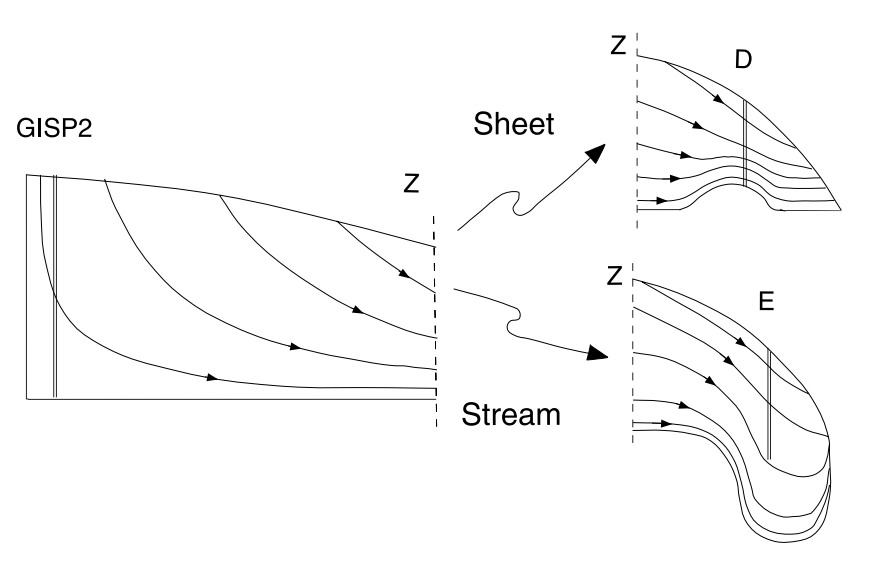

Fig. 14. Sketch of the deformation history assumed in interpreting the vertical deformation. The ice at ice-sheet drill site $D$ and at the ice-stream site $E$ was under similar conditions at some distant point Zupstream of the ice-stream confluence. The position of the GISP2 drill site is also sketched.

iant is $\tau=\sigma_{x z}$, and the enhancement factor for sensor $k$ at depth $h_{k}$ is

$$
E_{k}=\frac{\dot{\epsilon}_{x z, k}^{\text {meas }}}{C B(T) h_{k}^{n}} .
$$

The factor $C$ is $A_{0}(\rho g \sin \alpha)^{n}$ for a parallel-sided slab of inclination $\alpha$. Taking the average for all tilt sensors in the Holocene ice (above $680 \mathrm{~m}$ depth) as reference results in the enhancement factors in Table 2 and Figure 13. The variation of $E$ in the Holocene ice is smallest for a flow-law parameter of $n=2$ (in accordance with the modelling results discussed in Part II). The pre-Holocene ice shows a flow enhancement of 1.7 (for $n=3$ ) to $2.6(n=2)$. In the temperate ice near the base, the "enhancement" is $0.1-0.25$. This might be attributed either to a different ice crystallography or to the influence of the small-scale bedrock topography, altering the velocity field and thus the measured tilt angles.

Enhanced deformation of ice from the late Wisconsin has been reported for several sites in Greenland (Dahl-Jensen and Gundestrup, 1987; Shoji and Langway, 1988; Thorsteinsson and others, 1997, 1999). A possible explanation for this behaviour is the high content of impurities in the ice, leading to smaller ice crystals and rapid recrystallization (Paterson, 1991; Alley and Woods, 1996). In order to give an indication of the impurity content of the ice, calcium concentrations measured on the Greenland Ice Sheet Project 2 (GISP2) core are plotted in Figure 13 (the tentative depth scale is inferred from the matching procedure discussed in section 6.2.2; data from Mayewski and others, 1997, provided by the U.S. National Snow and Ice Data Center (NSIDG), University of Colorado at Boulder, and the World Data Center-A (WDC-A) for Paleoclimatology, U.S. National Geophysical Data Center, Boulder, Colorado). The similar variation of deformation rate with impurity content is in accordance with previous observations.

\subsubsection{Basal motion}

The basal velocity in the ice-stream-ice-sheet transition zone can be estimated with the velocity gradients measured at site $\mathrm{D}$, given in Table 2. Integrating a smooth interpolant through the measurements gives a contribution of ice deformation to the surface velocity of about $235 \mathrm{~m} \mathrm{a}^{-1}$ (solid line in Fig. 13). At a measured surface velocity of about $620 \mathrm{ma}^{-1}$ the ratio of basal motion amounts to $63 \%$.
Assuming that the high deformation rates occur throughout the pre-Holocene ice increases the total deformation to $260 \mathrm{~m} \mathrm{a}^{-1}$ (dashed-dotted line in Fig. 13) and results in a ratio of basal motion of $57 \%$. Such high ratios are probably not representative for large parts of the ice sheet. Indeed, the shearing transverse to the flow direction observed at the drill site (section 4.2) is different from ideal ice-sheet conditions and is due to the lateral drag of the ice stream.

Heat dissipated by friction during sliding over the bedrock or due to sediment deformation is mainly used to melt ice from the base. At a modelled basal shear stress of $8.7 \times 10^{4} \mathrm{~Pa}$ and a basal velocity of about $400 \mathrm{~m} \mathrm{a}^{-1}$ at site $\mathrm{D}$, about $0.1 \mathrm{~m} \mathrm{a}^{-1}$ of ice will melt at the base. Integrated over the zone with temperate bed conditions, the lowest $48 \mathrm{~m}$ of ice have been removed from an ice column reaching drill site $\mathrm{D}$.

\subsection{Vertical deformation history}

Differences in vertical deformation history between the ice stream and the adjacent ice sheet provide information on the mechanisms leading to the fast flow of the ice stream. Flowlines passing through drill sites D and E exhibit identical conditions (temperature profiles and internal layering structures) at some location $\mathrm{Z}$ upstream of the confluence area of the ice stream (Fig. 14). The large differences in the shapes of temperature profiles in the ice stream and at its margins (Fig. 7) provide evidence that the lower half of the ice is disproportionally stretched on its way into the bedrock trough. This was explained in Part I to be a consequence of a narrowing and deepening bedrock trough, leading to horizontally convergent flow of the basal ice.

The comparison of temperature profiles can only give a rough estimate of the stretching effect. Their precise form is strongly influenced by heat dissipation and the deformation history itself, leading to changing temperature gradients which in turn influence the temperature profile. A method which is unaffected by such complications is exploited below.

\subsubsection{CBC measurements}

A new method was devised to measure the relative vertical stretching in situ. With the aim of detecting layers of high conductivity, the variation of electric direct current between two electrodes in adjacent boreholes was logged. Since the boreholes refreeze after some hours, a bare wire was installed in one hole which served as a fixed line electrode upon refreezing. The second electrode, attached to an insulated wire, was lowered or lifted with constant velocity in a neighbouring borehole. A d.c. voltage of $20-200 \mathrm{~V}$ was applied between the electrodes, and the resulting current through the ice was measured with a high-precision ampere meter and registered with a data logger. The passage of marks on the cable was registered, and quasi-continuous logs of the current in intervals of $20 \pm 5 \mathrm{~cm}$ were obtained.

Several difficulties were encountered using this method. Measurements in the first four boreholes are only reliable at depths of $>500 \mathrm{~m}$. The currents measured in the upper part of the boreholes were always very high, noisy and not reproducible, presumably due to a contamination problem. Ice samples taken at the surface at $1 \mathrm{~km}$ distance from the drill site, and water from a river at the ice-stream site had conductivities of 7 and $5 \mu \mathrm{S}$, respectively (close to the conductivity of distilled water of $3.8 \mu \mathrm{S}$ ), whereas the conductivity of samples from drill site $\mathrm{D}$ was high $(30 \mu \mathrm{S})$. The cables were possibly contaminated with Diesel dust or oily gloves, 


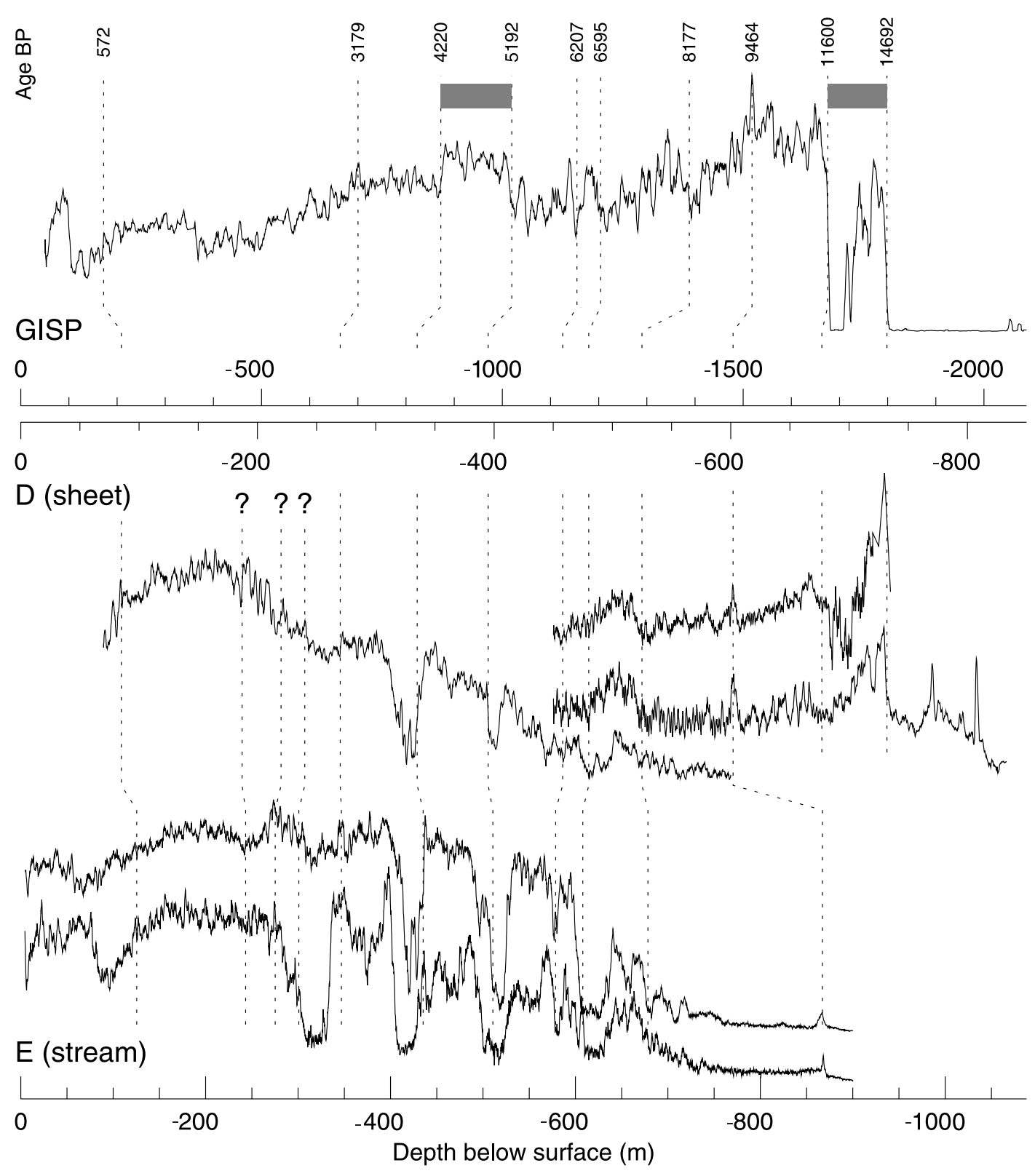

Fig. 15. CBC logs performed at site D (sheet) and site $E$ (stream) are plotted in arbitrary units on the vertical axis. Curves are shifted on the vertical axis for clarity. The depth scale for the ice sheet (middle scale) is stretched by 28\% with respect to the depth scale of the ice stream (lowest). Features considered identical are connected with dotted lines. Measurements performed with the ECM method on the GISP2 core are shown in the top plot (data from Taylor and others, 1997). The GISP2 depth scale is multiplied with a factor of 0.407 in order to approximately match features at drill sites $D$ and $E$. Key sequences for the identification are marked with grey bars. The age of several features is also given.

thus allowing currents to flow on the outside of the insulation and along the surface to the bare wire. Nevertheless, measurements from the bottom $350 \mathrm{~m}$ were reproducible and showed similar signals in experiments performed in different boreholes. The cable was specially protected against contamination in experiment CBC-7 at the icesheet drill site and also during both experiments performed at site $\mathrm{E}$ on the ice stream.

The distance between the holes and the line electrode was about $10-20 \mathrm{~m}$ at the surface (Fig. 5). Surprisingly high d.c. conductivities were encountered. For example, in log CBC- 6 a voltage of $30 \mathrm{~V}$ was applied between the electrodes separated some $10 \mathrm{~m}$. The resulting current varied from $1.2 \mathrm{~mA}$ near the surface to $50 \mu \mathrm{A}$ near the bed, resulting in apparent bulk resistances of $25-620 \mathrm{k} \Omega$. These low apparent bulk resistances are presumably due to the electrode geometry (a fixed line electrode and a moving electrode of $30 \mathrm{~cm}$ length). The measured current is therefore a signal smeared out over depth. Nevertheless, the signal exhibits distinct features which are reproducible in measurements from different boreholes (Fig. 15). The influence of ice temperature on the conductivity has been taken into account with an Arrhenius expression and an activation energy of $30 \mathrm{~kJ} \mathrm{~mol}^{-1}$ (Hobbs, 1974, p. 98; Hammer, 1980).

\subsubsection{Comparison of $C B C$ sequences}

The CBC logs at site D (sheet) and site E (stream) are compared in Figure 15. In an attempt to match similar sequences of conductivity variations in sheet and stream, the depth scale of the graph representing the ice sheet has been stretched by $28 \%$. The resulting similarity of the middle and lower curves is striking. Features considered to be identical are marked with dotted lines. The conductivity variations agree down to $700 \mathrm{~m}$ depth on the ice stream, or $550 \mathrm{~m}$ in the ice sheet. The single spike at $860 \mathrm{~m}$ in the ice stream is likely to correspond to $600 \mathrm{~m}$ in the ice sheet. 
The outlined matching procedure allows us to determine the differences in vertical stretching between sheet and stream. An ice layer located at $550 \mathrm{~m} \widehat{=} 0.66$ (on a relative depth scale) at the ice-sheet site is located at $700 \mathrm{~m} \widehat{=} 0.28$ at the ice-stream centre line. Thus the bottom $34 \%$ of the ice sheet corresponds to the lowest $72 \%$ of the ice stream. Consequently, the basal ice at $\mathrm{E}$ is stretched with respect to $\mathrm{D}$ by $642 \%$ ! This result agrees qualitatively with the non-uniform vertical stretching inferred from the comparison of the temperature profiles(section 4.6.1). The very high stretching value may, however, cast some doubt on the matching procedure we have applied.

\subsubsection{Comparison with the GISP2 core}

The CBC method bears some similarity to the ECM method used to determine d.c. conductivities of ice cores (Hammer, 1980; Taylor and others, 1997). A tentative comparison of our CBC measurements to the GISP2 ECM record is shown in Figure 15 (Taylor and others, 1997; data provided by NSIDC and WDC-A). The GISP2 depth scale is multiplied with a constant factor of 0.407 in order to simplify the comparison. Features considered identical to those of the $\mathrm{CBC}$ logs are marked with dotted lines. We believe that the sequence between 880 and $1000 \mathrm{~m}$, and especially the strong current variation at $1800 \mathrm{~m}$ depth (on the GISP2 depth scale, marked with grey bars), correspond to the sequence at 340-390 m depth and the variation at $730 \mathrm{~m}$ depth at site D. Provided this matching procedure applies, an absolute dating of the ice at sites D and E can be inferred. The decrease of electrical current at $730 \mathrm{~m}$ depth (at site D) would then correspond to 15600 years BP (before 1950), and the Holocene-Wisconsin transition (end of Younger Dryas at 11600 years BP) would be at $682 \mathrm{~m}$. The modelled Holocene-Wisconsin transition is at $680 \mathrm{~m}$ depth.

\subsection{Consequences for ice-stream dynamics}

The matching procedure outlined in sections 6.2.2 and 6.2.3 yields insights concerning the dynamics of the ice stream. If the correlation shown in Figure 15 is correct, this suggests that the Holocene-Wisconsin transition is at a depth of about $1100-1200 \mathrm{~m}$ at site E. Considerable portions of this $\sim 1300 \mathrm{~m}$ thick layer of pre-Holocene ice would show enhanced deformation properties. Since ice-stream flow is dominated by shear deformation which is the preferred stress state for enhanced deformation rates of anisotropic ice (Dahl-Jensen and Gundestrup, 1987; Thorsteinsson and others, 1997, 1999), very high shearing rates are expected. Further enhanced by the high ice temperatures, the internal deformation in the lower half of the ice stream could account for most of the ice-stream motion. This would also explain the observation that ice-stream velocities show no seasonal variations and are therefore not dominated by basal motion (Echelmeyer and Harrison, 1990).

Such a thick layer of pre-Holocene ice could form during the convergent flow into the ice stream. The warmer basal ice is channelized into the bedrock trough, whereas the overlying cold, rigid ice remains relatively unaffected. We conjecture that the azimuth of ice flow is changing with depth, and basal ice is forced sideways into the channel. This partial flow decoupling could result from the layer of "soft" Wisconsin ice which could act as a shear horizon.

While this line of reasoning is not entirely new (Part I; Clarke and Echelmeyer, 1996), the experimental evidence presented in this study strongly supports this hypothesis.

\section{CONGLUSIONS}

Borehole temperature measurements revealed a basal layer of temperate ice of $30 \mathrm{~m}$ thickness at site $\mathrm{D}$, adjacent to the ice stream. This corresponds to $3.7 \%$ of the ice thickness of $830 \mathrm{~m}$. Englacial temperatures were calculated with a flow model including heat diffusion, advection and allowing for phase transitions. The shape of the modelled temperature profile as well as the thickness of the temperate layer agree with the measurements. From the temperature gradient above the CTS and the modelled velocity field, a water content of $1 \%$ in the vicinity of the CTS was inferred. The measured melting-point depression at the bed corresponds to water with a low content of air and impurities, contrary to the assumption made in most modelling studies.

Variations in water pressure measured at the bottom of two boreholes allowed us to draw conclusions on the nature of the subglacial drainage system at the drill site. Large conduits were ruled out and the data are consistent with either a sediment layer, a gap conduit or a linked-cavity system. The measured hydraulic transmissivity of the basal drainage system is between $1 \times 10^{-5}$ and $1 \times 10^{-4} \mathrm{~m}^{2} \mathrm{~s}^{-1}$. Small diurnal variations in basal water pressure were observed, as well as one sudden large increase.

Measurements of borehole inclination at site $\mathrm{D}$ (ice sheet) showed that the ice of pre-Holocene origin undergoes strongly enhanced deformation. Integration of the inferred vertical gradients of horizontal velocity gives a contribution from deformation of $235-260 \mathrm{~m} \mathrm{a}^{-1}$ to the measured surface velocity of $620 \mathrm{~m} \mathrm{a}^{-1}$, and thus a ratio of basal motion of about $60 \%$. Such high basal velocities are probably not representative for the whole ice sheet, but for the lateral shear zone of the ice stream where drill site $\mathrm{D}$ was located. We expect a considerably lower ratio of basal motion in the ice stream, as the ice thickness is threefold and the temperate layer is at least 10 times thicker.

By logging of electrical currents between pairs of adjacent boreholes, specific patterns were recorded which could be matched to similar measurements in the ice stream. With a homogeneous vertical stretching of $28 \%$, the uppermost $550 \mathrm{~m}$ of the ice sheet correspond to the top $700 \mathrm{~m}$ in the ice stream. This corroborates the conclusion of previous studies (Iken and others, 1993; Funk and others, 1994), that both sites have very different deformation histories and that the basal ice is disproportionally stretched in the vertical direction on its way into the ice stream.

The combined interpretation of different types of data supports the conclusion of previous studies that the fast flow of Jakobshavn Isbræ is mainly due to high ice-deformation rates rather than basal motion. In addition to the previously conjectured mechanism of a thick layer of temperate ice which forms during flow into the bedrock trough, we found that up to $50 \%$ of ice in the ice stream is of pre-Holocene origin (if our matching of internal layers is correct). As measured at drill site $\mathrm{D}$, parts of this ice are much less viscous than the Holocene ice and thus are likely to play an important role during the convergent flow into the ice stream as well as during ice-stream flow.

\section{ACKNOWLEDGEMENTS}

We express our thanks to all who contributed to this project. The electronic transmission system was designed and built by H. P. Hächler and C. Senn. Assistance in the field was given 
by H. Bösch, P. Haffner, B. Jenny, H. Jenny, J. Luthiger and C. Senn. We acknowledge the support by KNI and the pilots and staff of Greenlandair. We thank K. Echelmeyer and T. Clarke for data on ice thickness and surface velocities; W. Krabill and W. Abdalati provided unpublished altitude data, and R. Forsberg gravity measurements of the Jakobshavn region. For their thorough comments which helped improve the manuscript, we are grateful to G. K. C. Clarke, N. Reeh, J. Meyssonnier and K. A. Echelmeyer. This project was funded by Swiss National Science Foundation grant No. 2139582.93 and ETH Zürich grant No. 0-20-982-95.

\section{REFERENCES}

Alley, R. B. and G. A. Woods. 1996. Impurity influence on normal grain growth in the GISP2 ice core, Greenland. F. Glaciol., 42(141), 255-260.

Blatter, H. and K. Hutter. 1991. Polythermal conditions in Arctic glaciers. $f$. Glaciol., 37(126), 261-269.

Budd, W. F., T. H. Jacka, D. Jenssen, U. Radok and N. W. Young. 1982. Derived physical characteristics of the Greenland ice sheet. Mark I. Parkville, Victoria, University of Melbourne. Meteorology Department. (Publication 23.)

Carbonnell, M. and A. Bauer. 1968. Exploitation des couvertures photographiques aériennes répétées du front des glaciers vêlant dans Disko Bugt et Umanak Fjord, juin-juillet, 1964. Medd. Grønl., 173(5).

Clarke, T. S. and K. Echelmeyer. 1996. Seismic-reflection evidence for a deep subglacial trough beneath Jakobshavns Isbræ, West Greenland. F. Glaciol., 42(141), 219-232.

Dahl-Jensen, D. and N. S. Gundestrup. 1987. Constitutive properties of ice at Dye 3, Greenland. International Association of Hydrological Sciences Publication 170 (Symposium at Vancouver 1987 - The Physical Basis of Ice Sheet Modelling), 31-43.

Echelmeyer, K. and W. D. Harrison. 1990. Jakobshavns Isbræ, West Greenland: seasonal variations in velocity - or lack thereof. f. Glaciol., 36(122), 82-88.

Echelmeyer, K., W. D. Harrison, T. S. Clarke and C. Benson. 1992. Surficial glaciology of Jakobshavns Isbræ, West Greenland: Part II. Ablation, accumulation and temperature. 7. Glaciol., 38(128), 169-181.

Engelhardt, H. and B. Kamb. 1997. Basal hydraulic system of a West Antarctic ice stream: constraints from borehole observations. f. Glaciol., 43(144), 207-230

Fabri, K., M. Funk and A. Iken. 1992. A sensitivity study for modelling ice temperatures in Jakobshavns-Isbræ, Greenland. VAW/ETHZ. Arbeitsheft 11.

Fastook, J. L., H. H. Brecher and T. J. Hughes. 1995. Derived bedrock elevations, strain rates and stresses from measured surface elevations and velocities: Jakobshavns Isbræ, Greenland. F. Glaciol., 41 (137), 161-173.

Fischer, U. H., N. R. Iverson, B. Hanson, R. LeB. Hooke and P. Jansson. 1998. Estimation of hydraulic properties of subglacial till from ploughmeter measurements. F. Glaciol., 44(148), 517-522.

Funk, M., K. Echelmeyer and A. Iken. 1994. Mechanisms of fast flow in Jakobshavns Isbræ, West Greenland: Part II. Modeling of englacial temperatures. f. Glaciol., 40(136), 569-585.

Gogineni, S., T. Chuah, C. Allen, K. Jezek and R. K. Moore. 1998. An improved coherent radar depth sounder. F. Glaciol., 44(148), 659-669.

Greve, R. 1997. Application of a polythermal three-dimensional ice sheet model to the Greenland ice sheet: response to steady-state and transient climate scenarios. 7. Climate, 10(5), 901-918.

Greve, R. and K. Hutter. 1995. Polythermal three-dimensional modelling of the Greenland ice sheet with varied geothermal heat flux. Ann. Glaciol., 21, 8-12.

Hammer, G. U. 1980. Acidity of polar ice cores in relation to absolute dating, past volcanism, and radio-echoes. 7. Glaciol., 25(93), 359-372.

Harrison, W. D. 1972. Temperature of a temperate glacier. f. Glaciol., 11(61), $15-29$.

Hobbs, P. V. 1974. Ice physics. Oxford, Clarendon Press.

Humphrey, N. and K. Echelmeyer. 1990. Hot-water drilling and bore-hole closure in cold ice. 7. Glaciol., 36(124), 287-298.

Hutter, K. 1993. Thermo-mechanically coupled ice-sheet response-cold, polythermal, temperate. F. Glaciol., 39(131), 65-86.

Huybrechts, P., T. Payne and the EISMINT Intercomparison Group. 1996. The EISMINT benchmarks for testing ice-sheet models. Ann. Glaciol., 23, 1-12.

Iken, A., K. Echelmeyer and W. D. Harrison. 1989. A light-weight hot water drill for large depth: experiences with drilling on Jakobshavns glacier Greenland. In Rado, C. and D. Beaudoing, eds. Ice core drilling. Proceedings of the Third International Workshop on Ice Drilling Technology, Grenoble - France, 10 14 October 1988. Grenoble, Centre National de la Recherche Scientifique. Laboratoire de Glaciologie et Géophysique de l'Environnement, 123-136.
Iken, A., K. Echelmeyer, W. Harrison and M. Funk. 1993. Mechanisms of fast flow in Jakobshavns Isbræ, West Greenland: Part I. Measurements of temperature and water level in deep boreholes. 7. Glaciol., 39(131), 15-25.

Jania, J., D. Mochnacki and B. Gadek. 1996. The thermal structure of Hansbreen, a tidewater glacier in southern Spitsbergen, Svalbard. Polar Res., 15(1), 53-66.

Kamb, B. 1987. Glacier surge mechanism based on linked cavity configuration of the basal water conduit system. F. Geophys. Res., 92(B9), 9083-9100.

Krabill, W. B., R. H. Thomas, C. F. Martin, R. N. Swift and E. B. Frederick. 1995. Accuracy of airborne laser altimetry over the Greenland ice sheet. Int. 7. Remote Sensing, 16 (7), 1211-1222.

Letréguilly, A., N. Reeh and P. Huybrechts. 1991. The Greenland ice sheet through the last glacial-interglacial cycle. Palaeogeogr., Palaeoclimatol., Palaeoecol., 90(4), 385-394.

Lingle, C. S., T. J. Hughes and R. C. Kollmeyer. 1981. Tidal flexure of Jakobshavns glacier, West Greenland. 7. Geophys. Res., 86(B5), 3960-3968.

Lliboutry, L. 1993. Internal melting and ice accretion at the bottom of temperate glaciers. F. Glaciol., 39(131), 50-64.

Lliboutry, L. and P. Duval. 1985. Various isotropic and anisotropic ices found in glaciers and polar ice caps and their corresponding rheologies. Ann. Geophysicae, 3(2), 207-224.

Lüthi, M. 1999. Rheology of cold firn and dynamics of a polythermal ice stream: studies on Colle Gnifetti and Jakobshavns Isbræ. Eidg. Tech. Hochschule, Zürich.Versuchsanst.Wasserbau, Hydrol. Glaziol. Mitt. 165.

Mayewski, P. A. and 6 others. 1997. Major features and forcing of high-latitude Northern Hemisphere atmospheric circulation using a 110,000year-long glaciochemical series. F. Geophys. Res., 102(C12), 26,345-26,366.

Ohmura, A. and N. Reeh. 1991. New precipitation and accumulation maps for Greenland. 7. Glaciol., 37(125), 140-148.

Paterson, W. S. B. 1991. Why ice-age ice is sometimes "soft". Cold Reg. Sci. Technol., $20(1), 75-98$.

Paterson, W.S.B. 1994. The physics of glaciers. Third edition. Oxford, etc., Elsevier.

Shoji, H. and C. C. Langway, Jr. 1988. Flow-law parameters of the Dye 3, Greenland, deep ice core. Ann. Glaciol., 10, 146-150.

Smith, G. D. and L.W. Morland. 1981. Viscous relations for the steady creep of polycrystalline ice. Cold Reg. Sci. Technol., 5(2), 141-150.

Stone, D. B. and G. K. C. Clarke. 1993. Estimation of subglacial hydraulic properties from induced changes in basal water pressure: a theoretical framework for borehole-response tests. 7. Glaciol., 39(132), 327-340.

Taylor, K. C., R. B. Alley, G. W. Lamorey and P. A. Mayewski. 1997. Electrical measurements on the Greenland Ice Sheet Project 2 core. 7. Geophys. Res., 102(C12), 26,511-26,517.

Thorsteinsson, Th., J. Kipfstuhl and H. Miller. 1997. Textures and fabrics in the GRIP ice core. F. Geophys. Res., 102(C12), 26,583-26,599.

Thorsteinsson, T., E. D. Waddington, K. C. Taylor, R. B. Alley and D. D. Blankenship. 1999. Strain-rate enhancement at Dye 3, Greenland. F. Glaciol., 45(150), 338-345.

Vallon, M., J.-R. Petit and B. Fabre. 1976. Study of an ice core to the bedrock in the accumulation zone of an Alpine glacier. F. Glaciol., 17(75), 13-28.

\section{APPENDIX A}

\section{INSTRUMENTATION OF THE BOREHOLES}

Five boreholes at site D were permanently instrumented with inclinometers, thermistors and pressure cells. Boreholes I1 and I2 were equipped with sensors attached to the telemetry system(section A.1). Three boreholes (T3-T5) were instrumented with thermistors over the whole depth range. The wiring of the sensors is shown in Figure 16. Horizontal lines indicate the time-span the sensors worked prior to rupture of the cables due to overstretching. It is not surprising to observe that all cables broke in the cold part where cables and sensors were frozen to the ice. 


\section{A.1. Telemetry system}

An electronic telemetry system was developed at the electronics workshop of VAW, ETH Zürich, with the design goals of high reliability, flexibility and low power consumption. The system was designed to measure many sensors over a single, long ( $>1000 \mathrm{~m}$ ) two-conductor cable which also served for the power supply. Technically this was achieved with a digital meter bus based on a "master-slave" concept. A data logger activates the main station (the master) which addresses a specific sensing unit (the slave). Upon request from the master, the slave reads an individually addressed sensor and, upon a further request, returns the corresponding sensor value which is stored in the data logger.

The meter bus system was developed at University of Paderborn, Germany(Prof. H. Ziegler), and Texas Instruments Germany. The signal processor was a Texas Instruments TSS400 with an integrated 12-bit analogue/digital converter, allowing a measurement resolution of $2^{12}-1=$ 4095 values. Data connection is bidirectional by either voltage pulses (from the master) or current pulses (from the slave). One master station is designed to address 32 slaves with four sensors each. Quiescent power consumption of the whole transmission system was about $1 \mathrm{~mA}$ at $3 \mathrm{~V}$. The system was fail-safe against short circuits, as the resistance of every cable segment was tested before a connection was established.

Two boreholes were equipped with nine (Il) and eight (I2) sensing units. Each unit consisted of the meter bus system (slave), a thermistor (Fenwal 192-101CAG-A01) and a biaxial tiltmeter (see below). The lowest unit in each hole was additionally equipped with a pressure sensor. All sensing units were protected against pressure in steel tubes of $750 \mathrm{~mm}$ length and $50 \mathrm{~mm}$ diameter that were filled with argon gas and a bag of desiccant. Watertight two-pole connectors (Subconn) were mounted on the top and bottom of each casing.

A special extendable cable (Cortland Cable Company) with six cores was sealed to the connectors (three cores in parallel gave a redundancy). A central Kevlar string, serving as strain relief, was mechanically attached to the sensor casings.

The master units of the telemetry systems were con- trolled by individual data loggers which periodically switched on the power supply, invoked the measuring commands and stored the instrument readings. Three Campbell CR10 loggers, each equipped with a storage module, were used to register data from boreholes I1, I2 and the three thermistor chains T3-T5. Through this set-up, all three data logging systems were operated independently, which resulted in a higher reliability.

\section{A.2. Sensor calibration}

\section{Tilt sensors}

The tiltmeters consisted of biaxial electrolytic tilt cells with a measurement range of $\pm 15^{\circ}$ (HL-Planartechnik GmbH, HLPlanar NS15/R2). The tilt sensors were calibrated individually at 200 precisely known tilt angles. The angle resolution thus obtained is $\pm 0.01^{\circ}$ with an absolute accuracy of $\pm 0.02^{\circ}$. All tilt sensors were measured with the telemetry system described above, allowing again an angle resolution of $\pm 0.01^{\circ}$.

\section{Thermistors}

Boreholes T3-T5 were equipped with thermistors mounted on multi-core cables. Measurements were performed with a data logger at the surface, connected to appropriate resistivity bridges. Depending on the expected temperatures, different negative temperature coefficient thermistors were used (Fenwal 135-103FAF-J01 and 135-302FAF-J01). To protect the thermistors against the influence of pressure and humidity, they were sealed into polyamide tubes. All thermistors (including those of the telemetry system) were calibrated in an ice-water bath and at several cold temperatures in the expected measurement range in a mixture of water and antifreeze. The temperature of the bath was measured with four reference temperature probes calibrated to an accuracy of $\pm 0.03^{\circ} \mathrm{C}\left( \pm 0.04^{\circ} \mathrm{C}\right.$ below $\left.-12^{\circ} \mathrm{C}\right)$ by the Swiss Federal Office of Metrology. From the measurements at four or five temperatures, a calibration curve was calculated for each individual thermistor. This gives an absolute accuracy of $\pm 0.03^{\circ} \mathrm{C}$ near the freezing point and $\pm 0.05^{\circ} \mathrm{C}$ at temperatures below $-10^{\circ} \mathrm{C}$.
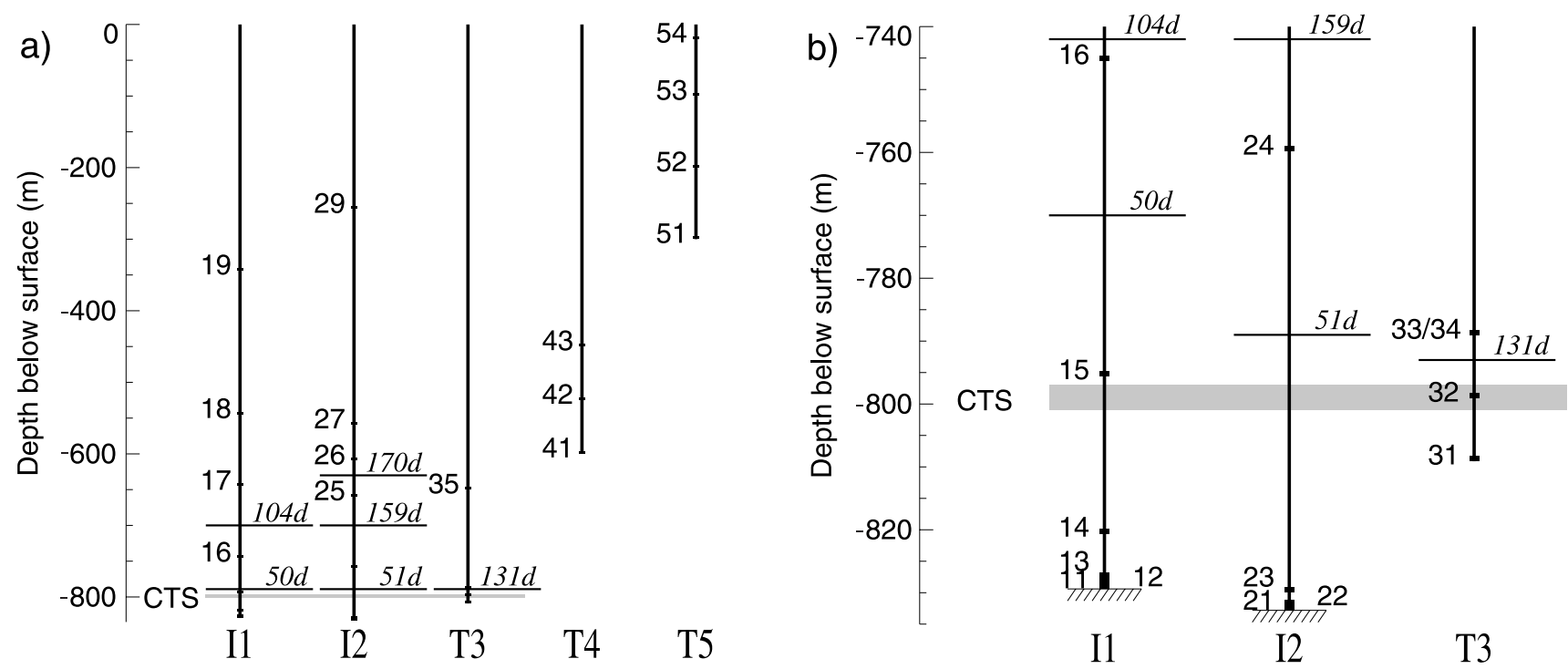

Fig. 16. Depth below surface and wiring of the sensor cables. Inclinometer casings, containing tilt sensors and thermistors, are on cables I1 and I2, and thermistors on cables T3- T5, corresponding to the designations in Figure 5. Sensor depths are indicated with squares and are annotated with two-digit numbers. The temperate basal layer is below the grey bar (CTS). All sensors near the glacier base worked for a limited time period until the cable broke due to overstretching. Annotations in italics indicate the duration in days that the cable segments worked. (b) An enlarged view of the sensors near bedrock. 

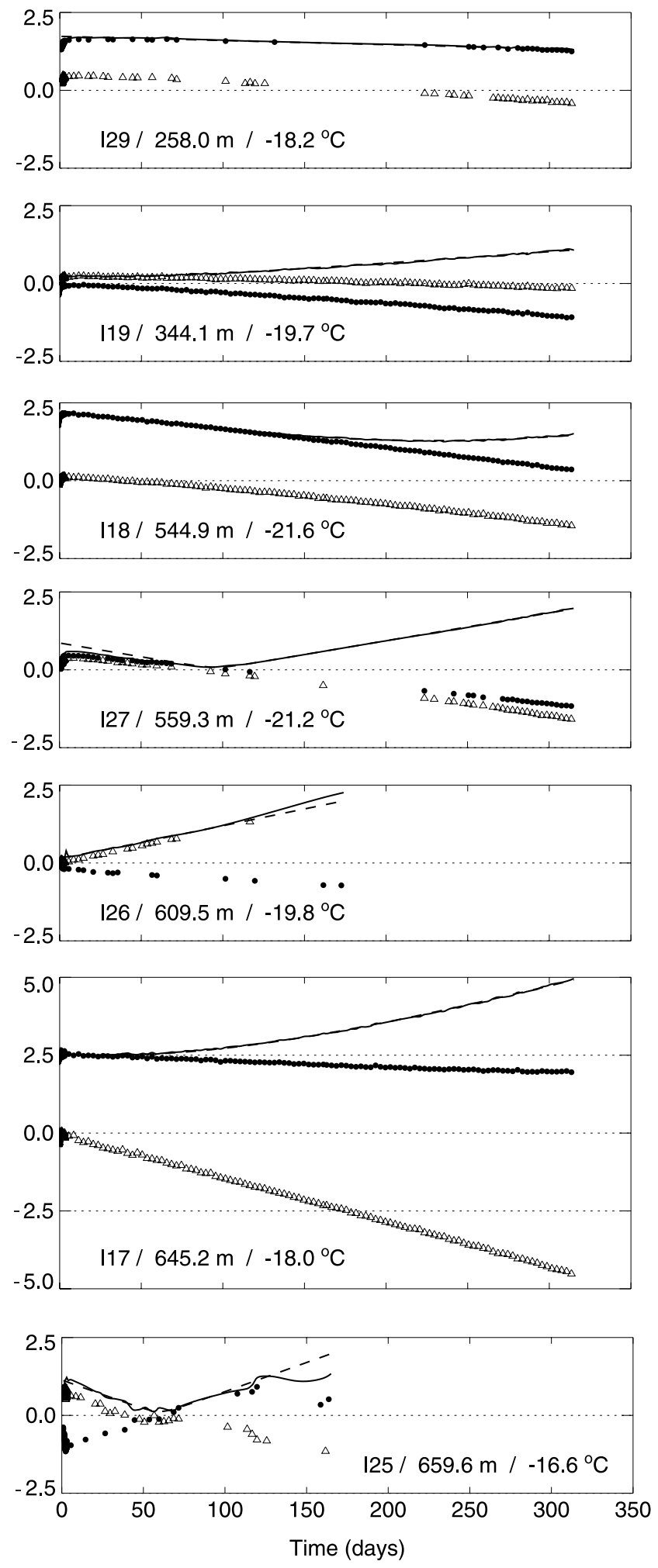

Fig. 17. Measured tilt angles in degrees (vertical scale) are plotted vs time for the tiltmeters installed at depths $<700 \mathrm{~m}$. Tilt-angle measurements are indicated with solid dots and triangles for the instrument $x$ and $y$ axis. The interpolated total tilt is plotted with a thick solid line. The dashed line is the result of an interpretation of the measurements in terms of simple shear.
Pressure cells

Two pressure cells (Keller PA-10-200), labelled P1 and P2, in the lowermost sensing units of the telemetry system were installed at the bottom of boreholes Il and I2. The instruments were calibrated during lowering of the cable into the borehole. The stretching of the cables by the increasing weight of sensor casings and the cable suspended in the borehole was accounted for in the calibration curve (the elastic modulus of the cables has been measured by Swiss Federal Laboratories for Materials Testing and Research (EMPA). Finally, the calibration curve was adjusted to borehole water levels measured with a sounding float.

The resolution of the water-level measurements with the digital transmission system was $\sim 0.5 \mathrm{~m}$, and the linear calibration curve has a standard deviation of $0.7 \mathrm{~m}$. Water levels measured with the float switch are accurate to some centimetres. Since the borehole water level slightly changed while the inclinometers were submerged, the absolute accuracy is of the order $\pm 1 \mathrm{~Pa}( \pm 1 \mathrm{~m}$ water level).

\section{APPENDIX B \\ INGLINOMETER READINGS}

All measured tilt angles are plotted vs time in Figures 17 and 18. Most tilt angles vary steadily with time, eventually passing a minimal total inclination, for example after 200 days for I18 and after 90 days for I27 (Fig. 17). This occurs if an inclinometer initially tilted in the upstream direction is rotated through the vertical during ice deformation. A non-zero minimal tilt angle indicates that the sensor is inclined in a direction perpendicular to the main ice flow. Some inclinometers in the temperate basal part of the ice rotate around the instrument axis, but still undergo steady ice deformation (e.g. I15 and I23, Fig. 18). Only two inclinometers show anomalous behaviour. We interpret the change in tilt angle after 20 days at I14 as being caused by a motion of the sensor casing in the unfrozen borehole, presumably caused by cable tension. Inclinometer I 25 which is frozen to the ice, shows a strongly irregular behaviour.

Sensor readings of inclinometers I21-I29 are partially missing during winter, due to a malfunction of the telemetry system connected to the cable in borehole I2. The master bus only worked satisfactorily when temperatures in the logger box exceeded $-5^{\circ} \mathrm{C}$, possibly due to time-out problems in the sensor communication. Since all measurements follow the general trend and are continuous in spring, we assume that the values recorded in winter are reliable. The telemetry system installed in borehole Il was not affected by this problem. 

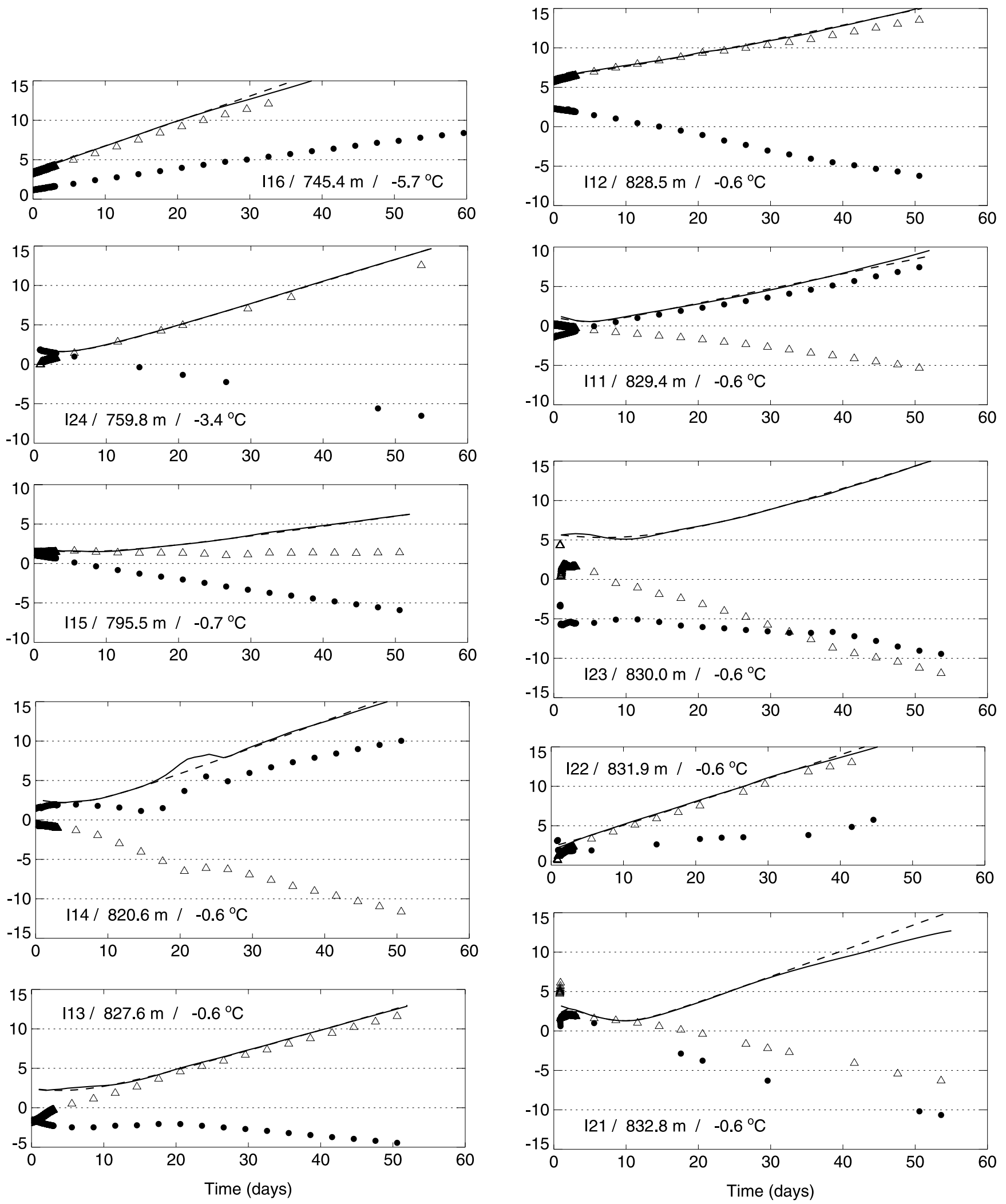

Fig. 18. Tilt angles of inclinometers located below $700 \mathrm{~m}$. See Figure 17.

MS received 21 June 2001 and accepted in revised form 8 May 2002 